\title{
Causas y consecuencias de las lluvias extraordinarias de 2017 en la costa ecuatoriana: el caso de la provincia Manabí
}

\section{Causes and consequences of the extraordinary rainfall of 2017 on the Ecuadorian coast: The case of the province of Manabí}

\author{
Henry Pacheco ${ }^{1 *}$, Argenis Montilla ${ }^{2}$, Williams Méndez ${ }^{3,4}$, María Hipatia Delgado ${ }^{5}$ y Diana Zambrano ${ }^{6}$ \\ $\begin{array}{llll}0000-0002-9997-9591 & \text { (D) } 0000-0001-9739-4971 & \text { (D) } 0000-0002-7345-2281 & \text { (D) } 0000-0002-5815-8981\end{array}$
}

1. Departamento de Ingeniería Agrícola, Facultad de Ingeniería Agrícola, Universidad Técnica de Manabí. Lodana, Santa Ana, EC 13132, Manabí Ecuador.henrypacheco@gmail.com.*Autor para correspondencia

2. Facultad de Hotelería y Turismo, Universidad Laica Eloy Alfaro de Manabí. Manta, EC 130802, Manabí.Ecuador.argenismontilla@hotmail.com.

3. Departamento de Construcciones Civiles, Facultad de Ciencias Matemáticas, Físicas y Químicas, Universidad Técnica de Manabí. Portoviejo, EC 130105, Manabi.Ecuador.williamsmendez@gmail.com.

4. Centro de Investigación Estudios del Medio Físico Venezolano, Instituto Pedagógico de Caracas, Universidad Pedagógica Experimental Libertador. El Paraíso 1020, Caracas, Distrito Capital. Venezuela

5. Facultad de Ciencias Veterinarias, Universidad Técnica de Manabí.Lodana, Santa Ana, EC 13132, Manabí.Ecuador. hipatiademera@hotmail.com

6. Departamento de Gestión Ambiental, Universidad Laica Eloy Alfaro de Manabí.Manta, EC 130802, Manabí.Ecuador.dizamca@hotmail.com.

\section{RESUMEN}

L

os eventos de lluvias extraordinarias son objeto de investigación en distintas regiones del mundo, donde su ocurrencia ha provocado impactos socio-ambientales negativos, expresados en cuantiosas pérdidas humanas y materiales. El objetivo de este trabajo es analizar las causas y

consecuencias de las lluvias extraordinarias registradas en Manabí en febrero y marzo de 2017, haciendo énfasis en las afectaciones de orden social, económico y ambiental. Se asume como supuesto, que estos eventos guardan estrecha relación con las anomalías de la temperatura superficial del mar en el océano Pacífico ecuatorial. Se realizó una investigación de campo mediante el análisis de datos de temperatura superficial del mar (TSM) en imágenes de satélite, empleando el algoritmo matemático Split Night Multi Channel Sea Surface Temperature, el cual permite identificar anomalías térmicas. Con los registros de precipitación de estaciones meteorológicas de la región costera ecuatoriana, se realizó un análisis estadístico descriptivo, para conocer el comportamiento anual (régimen) e histórico de las lluvias. Las afectaciones socio-económicas se estudiaron a partir de entrevistas no estructuradas a informantes clave, a través de un muestreo no probabilístico, así como información primaria de organismos gubernamentales. Los resultados indican que las lluvias extraordinarias observadas durante el período febrero-marzo de 2017 fueron consecuencia de la conjugación de factores como anomalías térmicas positivas en el Pacífico ecuatorial, convergencia intertropical e inestabilidad atmosférica en la Amazonía. Esto generó impactos negativos en localidades urbanas y rurales como Manta, Portoviejo, Lodana, Calceta y Chone.

PALABRAS CLAVE: Lluvias extraordinarias, Anomalías térmicas, Convergencia intertropical, Desastres socio-naturales, Pacífico ecuatorial.

\section{ABSTRACT}

$\mathrm{E}$ xtraordinary rainfall events are the object of research in different parts of the world, where their occurrence has caused negative socioenvironmental impacts, expressed in substantial human and material losses. The objective of this work is to analyze the causes and consequences of the extraordinary rains registered in Manabí in February and March 2017, emphasizing its social, economic and environmental effects. It is assumed that these events are closely related to the anomalies of sea surface temperature in the equatorial Pacific Ocean. Field research was conducted by analyzing sea surface temperature (SST) data in satellite imagery using the Split Night Multi Channel Sea Surface Temperature algorithm to identify thermal anomalies. With the precipitation records of meteorological stations of the Ecuadorian coastal region, a descriptive statistical analysis was conducted to determine the annual behavior (regime) and historical rainfall. Socioeconomic impacts were studied from unstructured interviews with key informants, through non-probability sampling, as well as primary information from government agencies. The results indicate that the extraordinary rains observed during the February-March 2017 period were a consequence of the combination of factors such as positive thermal anomalies in the equatorial Pacific, intertropical convergence and atmospheric instability in the Amazon. This generated negative impacts in urban and rural localities such as Manta, Portoviejo, Lodana, Calceta and Chone.

KEYWORDS: Extraordinary rains, Thermal anomalies, Intertropical convergence, Socio-natural disasters, Equatorial Pacific. 


\section{INTRODUCCIÓN}

Los fenómenos y/o procesos naturales como huracanes, erupciones volcánicas, incendios forestales, terremotos, inundaciones, deslizamientos y lluvias extraordinarias, entre otros, alteran el curso de los asentamientos y actividades humanas (Pérez, 1983). Estos fenómenos ponen en franco peligro, no solamente a los ecosistemas, sino también a los grupos humanos, fundamentalmente cuando se convierten en hechos catastróficos acompañados con importantes cifras de víctimas fatales y cuantiosos daños materiales, así como serias conmociones en la salud pública (Organización Panamericana de la Salud [OPS], 2000; Ortiz, 2000).

Las lluvias extraordinarias causan extensas inundaciones que desarticulan los medios de producción de las poblaciones urbanas y rurales en todo el mundo. Registros del Centro de Investigación sobre la Epidemiología de los Desastres [CRED, por sus siglas en inglés] (2004) consideran que, a nivel mundial, las inundaciones son los eventos que, con alta recurrencia, generan las peores catástrofes, con serias repercusiones en la economía de las regiones afectadas. La base internacional de datos de desastres elaborada por el CRED (Oficina de Asistencia para Casos de Desastre en el Extranjero [OFDA, por sus siglas en inglés] - CRED Database), registra una cifra superior a siete millones de personas en todo el mundo, como víctimas de inundaciones durante el período 1900-2001, entre las que destacan como los escenarios de mayor impacto, las producidas por el río Yangtsé (China) en 1931, que ocasionó la pérdida de 3.700 .000 vidas $\mathrm{y}$, en 1998 , durante la cual 238.973.000 habitantes fueron afectados.

Según el Ministerio del Ambiente de Ecuador [MAE] (2011), 35\% de la población ecuatoriana vive en zonas amenazadas por las inundaciones e históricamente, se han presentado lluvias extraordinarias durante la ocurrencia del evento conocido como fenómeno El Niño. Por ejemplo, para el episodio de 1982 se registraron 307 fallecidos, 700.000 personas afectadas y numerosos tramos de carreteras destruidas. Posteriormente, en el período $1997-$ 98, otro evento Niño produjo 293 víctimas fatales, 13374 hogares afectados, así como daños estimados en más de 880 millones de USD (Organización de las Naciones Unidas para la Alimentación y la Agricultura [FAO, por sus siglas en inglés], s.f.).

Eventos de lluvias extraordinarias no asociadas al fenómeno El Niño se han registrado en la costa ecuatoriana

\section{INTRODUCTION}

Natural phenomena and/or processes such as hurricanes, volcanic eruptions, forest fires, earthquakes, floods, landslides and extraordinary rainfall, among others, alter the course of human settlements and activities (Pérez, 1983). These phenomena clearly endanger ecosystems and human groups, fundamentally when they become catastrophic events accompanied by significant numbers of fatalities and substantial material damage, as well as causing serious commotions in terms of public health (Pan American Health Organization [PAHO], 2000; Ortiz, 2000).

Extraordinary rainfall causes extensive flooding that disrupts the means of production for urban and rural populations around the world. Reports of the Centre for Research on the Epidemiology of Disasters [CRED] (2004) consider that, at a global level, floods are the events that, with high recurrence, generate the worst catastrophes, with serious repercussions on the economy of the affected regions. The international database of disasters developed by CRED (Office of Foreign Disaster Assistance [OFDA] - CRED Database), reports a figure of more than seven million people worldwide, as victims of floods during the 1900-2001 period, among which those produced by the Yangtze River (China) in 1931, which caused the loss of $3,700,000$ lives and, in 1998, during which 238,973,000 inhabitants were affected.

According to Ecuador's Ministry of the Environment [MAE] (2011), 35\% of the Ecuadorian population lives in areas threatened by floods and historically, extraordinary rainfall has occurred during the event known as the El Niño phenomenon. For example, for the 1982 episode there were 307 deaths, 700,000 people affected and numerous sections of roads destroyed. Subsequently, in the 1997-98 period, another El Niño event resulted in 293 fatalities, 13374 affected homes, and damage estimated at more than USD 880 million (Food and Agriculture Organization [FAO], s.f.). Extraordinary rainfall events not associated with the El Niño phenomenon have been recorded on the Ecuadorian coast at different times. In 1993, high amounts of rainfall activated landslides that caused 110 fatalities, with damage to more than 740 houses and significant damage to crops, totaling nearly 150 million USD in losses. A similar situation arose in 2008 in the province of Manabí, as a result of heavy rains that left 62 dead, 9 missing, more than 90000 families affected and some 150000 ha of lost crops (FAO, s.f.). 
en diferentes momentos. En 1993, elevados montos pluviométricos activaron deslizamientos de tierra que ocasionaron 110 víctimas fatales, con daños a más de 740 viviendas y estragos importantes en cultivos, que totalizaron cerca de 150 millones de USD en pérdidas. Una situación similar a la anterior se presentó en 2008 en la provincia Manabí, como consecuencia de fuertes precipitaciones que dejaron un saldo de 62 fallecidos, 9 desaparecidos, más de 90000 familias damnificadas y unas 150000 ha de cultivos perdidos (FAO, s.f.).

En 2017, específicamente en los primeros cuatro meses, pero con mayor intensidad en febrero y marzo, se registraron elevados montos de lluvia, valores que superaron significativamente a los promedios históricos, trayendo como consecuencia severos impactos a nivel social y ambiental. La manifestación de las precipitaciones atípicas se dejó sentir en toda la costa ecuatoriana, incluso en países vecinos como Perú y Colombia. Para el caso de Ecuador, la mayoría de estas precipitaciones se concentró justamente en aquellas localidades que previamente habían sido afectadas por el sismo de abril de 2016.

Las aguas pluviales encontraron severos daños preexistentes en las estructuras hidráulicas de los sistemas multipropósito, lo que afectó de manera significativa áreas urbanas y rurales, desarticulando la cotidianidad de sus habitantes, pues lejos de haberse recuperado totalmente de los daños del evento sísmico, se les sumaron los impactos del fenómeno meteorológico en cuestión. Estas lluvias extraordinarias afectaron intensamente el suelo (activación de procesos erosivos), sobre todo a los desarrollados en laderas, considerando que éste es uno los recursos más preciados por la población manabita, la cual se dedica en más de $60 \%$ a las actividades agropecuarias, (INEC, 2010). Según Vega et al. (2013), los efectos de las lluvias extraordinarias sobre el suelo se traducen en procesos erosivos caracterizados por ser recurrentes, progresivos e irreversibles y, el hombre difícilmente puede resarcirlos, peor aun cuando los registros históricos muestran tendencias determinadas por un incremento en la intensidad de las precipitaciones, tal como García y Cruz (2009) lo registran para México.

Considerando el escenario de desastre de 2017, registrado para la costa ecuatoriana, fue objetivo de este trabajo analizar las causas y consecuencias de las lluvias extraordinarias registradas en Manabí en los meses de febrero y marzo de 2017, haciendo énfasis en las afectaciones de orden social, económico y ambiental. Los
In 2017, specifically in the first four months, but with greater intensity in February and April, high rainfall was recorded with values that significantly surpassed the historical averages, causing severe social and environmental impacts. The manifestation of this atypical rainfall was felt throughout the Ecuadorian coast, even in neighboring countries such as Peru and Colombia. In the case of Ecuador, the majority of these precipitations were concentrated precisely in those localities that had previously been affected by the earthquake of April 2016.

The rainwater worsened the severe pre-existing damage to the hydraulic structures of multipurpose systems, which significantly affected urban and rural areas, disrupting the daily lives of their inhabitants. Indeed, far from having fully recovered from the damage of the seismic event, the impacts of the meteorological phenomenon in question were added to them. The extraordinary rainfall affected the soil through the activation of erosive processes especially on the slopes, which is particularly damaging given that over $60 \%$ of the population of Manabí works in agriculture (INEC, 2010).

According to Vega et al. (2013), the effects of the extraordinary rainfall on the soil lead to erosive processes characterized by being recurrent, progressive, and irreversible. They are very difficult to repair, and even more so when historical records show trends determined by an increase in the intensity of rainfall, as reported by García and Cruz (2009) for Mexico.

Considering the 2017 disaster scenario reported for the Ecuadorian coast, the objective of this work was to analyze the causes and consequences of the extraordinary rainfall recorded in Manabí in February and March 2017, emphasizing social, economic and environmental effects. The results of this research can contribute to decisionmaking aimed at improving the conditions of the population and a new spatial reorganization, and to tackle future socionatural events of extreme magnitudes with greater success and resilience. In this regard, Gelcer et al. (2018) argue that using climatic information can reduce risks and propose favorable conditions for crop development. It is assumed that positive thermal anomalies in the equatorial Pacific positively affect the occurrence of extraordinary rainfall, which given its high intensity, causes strong impacts on the socio-environmental conditions of the inhabitants in the study area. 
resultados de esta investigación pueden contribuir en la toma de decisiones, orientadas a mejorar las condiciones de la población y a una nueva reorganización espacial, para enfrentar con mayor éxito y resiliencia, futuros eventos socio-naturales de magnitudes extremas. Al respecto, Gelcer et al. (2018) sostienen que utilizando información climática se pueden reducir los riesgos y, proponer condiciones favorables para el desarrollo de cultivos. Se parte del supuesto que las anomalías térmicas positivas en el Pacífico ecuatorial, inciden positivamente en la ocurrencia de lluvias extraordinarias; este tipo de precipitaciones por su alta intensidad provocan fuertes impactos en las condiciones socioambientales de los habitantes en el área de estudio.

\section{ÁREA DE ESTUDIO}

El área de estudio se localiza en la provincia de Manabí, en la costa noroccidental pacífica de Ecuador, definida por las coordenadas geoastronómicas $0^{\circ} 55^{\prime} 44^{\prime \prime} \mathrm{N}$ $1^{\circ} 55^{\prime} 34^{\prime \prime}$ S y $79^{\circ} 23^{\prime} 41^{\prime \prime}$ - $80^{\circ} 23^{\prime} 07^{\prime \prime}$ Oeste, abarcando una superficie de $18.940 \mathrm{~km}^{2}$, donde se asienta una población cercana a 1.5 millones de habitantes (Figura 1). La litología está constituida por más de $90 \%$ de rocas sedimentarias de edades terciarias y cuaternarias, poco consolidadas y con estratificación indefinida. Los principales tipos de rocas expuestas son lutitas arcillosas, limolitas y areniscas pobremente cementadas (Aguirre y Chávez, 2009).

El relieve está representado principalmente por grandes llanuras costeras y valles fluviales, así como algunos sistemas montañosos con elevaciones máximas de $853 \mathrm{msnm}$. Los principales sistemas fluviales están conformados por las cuencas de drenaje de los ríos Chone y Portoviejo.

El clima presenta regímenes de lluvias unimodales, con una concentración muy marcada y más de nueve meses secos en la costa con totales anuales inferiores a $200 \mathrm{~mm}$ y un incremento progresivo en la dirección O-E hasta llegar a $3000 \mathrm{~mm}$ anuales en el sector noreste de la provincia. Los suelos residuales están compuestos principalmente de arcillas muy plásticas y expansivas. También existen grandes áreas cubiertas de limo que tienen un alto grado de colapsabilidad y materiales de dispersión. Estos materiales son fáciles de movilizar y tan pronto como se excavan, pierden sus propiedades de resistencia y se vuelven fácilmente erosionables por la acción de la escorrentía (Aguirre y Chávez, 2009).

\section{STUDY AREA}

The study area is located in the province of Manabí, on the Pacific Northwest coast of Ecuador, defined by geoastronomical coordinates $0^{\circ} 55^{\prime} 44^{\prime \prime} \mathrm{N}-1^{\circ} 55^{\prime} 34^{\prime \prime} \mathrm{S}$ and $79^{\circ} 23^{\prime} 41^{\prime \prime}-80^{\circ} 23^{\prime} 07^{\prime \prime} \mathrm{W}$, covering an area of 18,940 $\mathrm{km}^{2}$, and with a population of about 1.5 million inhabitants (Figure 1). The lithology is constituted by more than $90 \%$ of sedimentary rocks of tertiary and quaternary eras, little consolidated and with indefinite stratification. The main types of exposed rocks are clayey shale, siltstones, and poorly cemented sandstones (Aguirre y Chávez, 2009).

The relief is represented mainly by large coastal plains and river valleys, as well as some mountain systems with maximum elevations of $853 \mathrm{~m}$ above sea level. The main river systems are formed by the drainage basins of the Chone and Portoviejo rivers.

The climate presents unimodal rainfall regimes, with a very pronounced concentration and more than nine dry months on the coast with annual totals below $200 \mathrm{~mm}$ and a progressive increase in the direction W-E to reach $3000 \mathrm{~mm}$ annually in the northeastern sector of the province. The residual soils are mainly composed of very elastic and expansive clays. There are also large areas covered with silt that have a high degree of collapsibility and dispersion materials. These materials are easy to move and as soon as they are excavated, they lose their resistance properties and become easily eroded by the action of runoff (Aguirre and Chávez, 2009).

The use and coverage of the space are mainly agricultural and pasture, making it the first province in Ecuador in terms of total agricultural land $(1,643,428 \mathrm{ha})$ (National Statistics and Census Institute [INEC], 2010), covering $21.16 \%$ of the country, with productive activities in the economic sector that represent $14 \%$ of the provincial gross value added (Central Bank of Ecuador [ECB], 2014) and $37.1 \%$ of the economically active population (INEC, 2010). This productivity is mainly based on family farming, occupying an average area of 4 ha per farmer (Monteros and Salvador, 2015).

\section{MATERIALS AND METHODS}

\section{Analysis of satellite information}

This study used remote images generated from thermal sensors installed in meteorological satellites of the NOAA (National Oceanic Atmospheric Administration), 


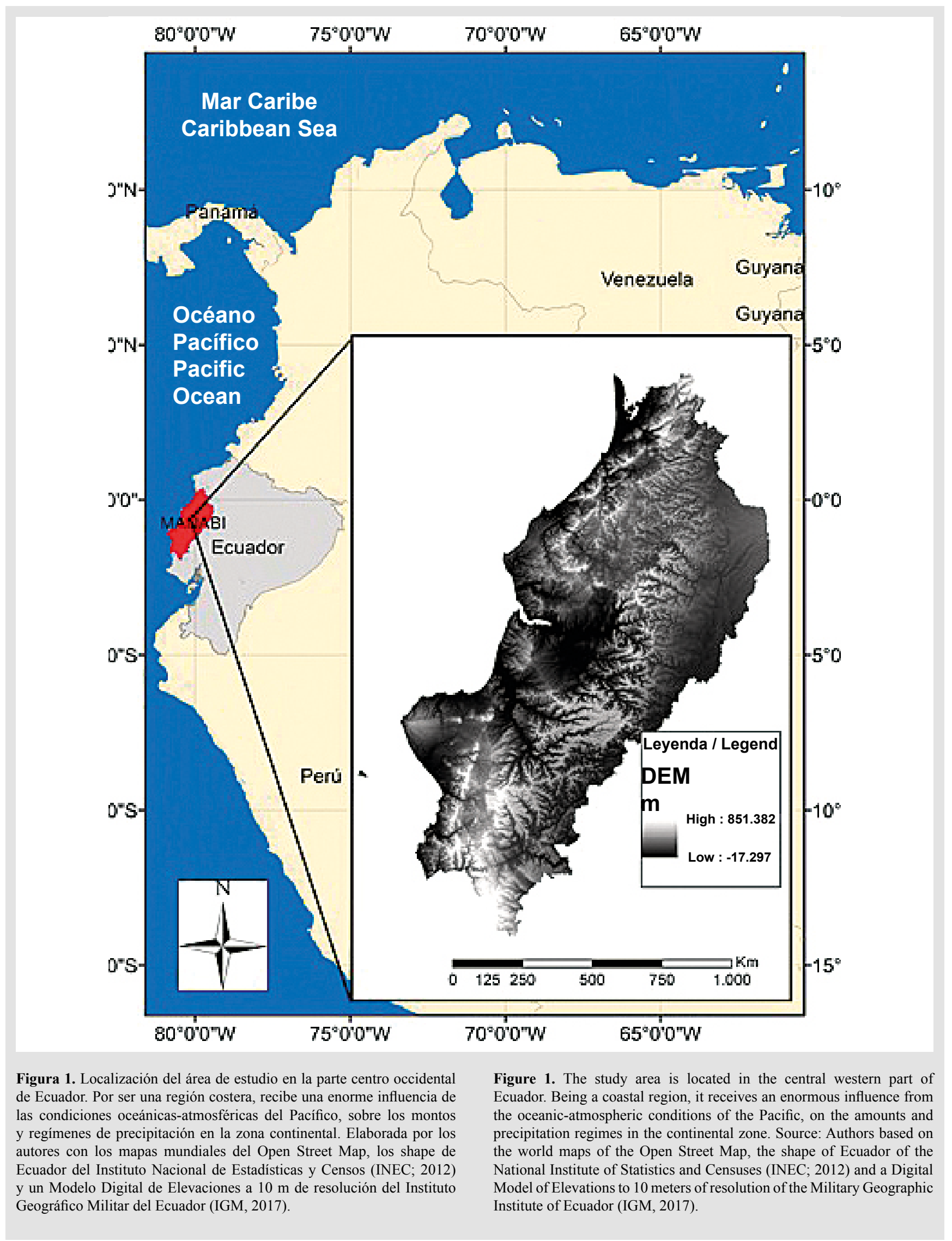


El uso y la cobertura del espacio son principalmente agrícola y de pastos, siendo la primera provincia de Ecuador en el total de tierras agrícolas (1643428 ha) (Instituto Nacional de Estadística y Censo [INEC], 2010). Esto significa $21,16 \%$ en el país, con actividades productivas en el sector económico que, representan $14 \%$ del valor agregado bruto provincial (Banco Central del Ecuador [BCE], 2014) y $37,1 \%$ de la población económicamente activa (INEC, 2010). Esta productividad se sustenta principalmente en la agricultura familiar, ocupando áreas promedio de 4 ha por agricultor (Monteros y Salvador, 2015).

\section{MATERIALES Y MÉTODOS}

\section{Análisis de la información satelital}

Para efectos de la presente investigación, se requirió de imágenes remotas generadas a partir de sensores térmicos instalados en satélites meteorológicos de la NOAA (National Oceanic Atmospheric Administration), NCEP (National Center for Environmental Prediction) y Emcglobal (Environmental Modeling Center), responsables de las operaciones y mantenimiento de más de 20 sistemas de predicción numérica. Las imágenes de temperatura superficial del mar (TSM) se obtuvieron por el generador de mapas del Centro Internacional para la Investigación del Fenómeno de El Niño (CIIFEN), el cual fue designado a pedidos de los Servicios Meteorológicos del Oeste de Sudamérica como Centro Regional del Clima (CRC) de la Organización Meteorológica Mundial (WMO, por sus siglas en inglés). Con tal designación la institución expandió su ámbito de acción hacia la provisión de datos e información climática de la región. (CIIFEN, 2017).

El procedimiento para generar las imágenes de TSS, descrito por Cañón (sf), consiste en descargar los datos captados por el sensor AVHRR, a bordo de la plataforma satelital NOAA, sobre la superficie oceánica. La información posteriormente se decodifica en cualquier software para procesamiento digital de imágenes, (tipo ERDAS Imagen), que cuenten con el módulo de procesamiento HRPT (High Resolution Picture Transmission). Los criterios que se consideran para el procesamiento de la información, además de la cobertura espacial seleccionada, son la nubosidad y la corrección geométrica. Para la corrección de efectos atmosféricos, se utiliza el algoritmo Split Night Multi Channel Sea Surface Temperature (SST), permitiendo así convertir la información recibida (valores digitales leídos
NCEP (National Center for Environmental Prediction) and EMCGLOBAL (Environmental Modeling Center), responsible for the operations and maintenance of more than 20 numerical prediction systems. The sea surface temperature (SST) images were obtained by the map generator at the International Center for Research on the El Niño Phenomenon (CIIFEN), which was designated at the request of the Western South American Meteorological Services as the Regional Climate Center (CRC) of the World Meteorological Organization (WMO). With this designation, the institution expanded its scope of action towards the provision of climate data and information for the region (CIIFEN, 2017).

The procedure to generate TSS images, described by Cañon (sf), consists of downloading the data captured by the AVHRR sensor, on board the NOAA satellite platform, on the ocean surface. The information is then decoded in any digital image processing software (ERDAS Image type) with HRPT (High Resolution Picture Transmission) processing module. The criteria considered for information processing, in addition to the spatial coverage selected, are cloud cover and geometric correction. For the correction of atmospheric effects, the Split Night Multi - Channel Sea Surface Temperature (SST) algorithm is used, thus allowing the conversion of the information received (digital values read by the satellite) to sea surface temperature, from the radiantics received in channels $4(10.50 \mu \mathrm{m}-11.30$ $\mu \mathrm{m})$ and $5(11.50 \mu \mathrm{m}-12.50 \mu \mathrm{m})$, where the radiation emitted by the surface is captured in the thermal infrared. Subsequently, the information (already in SST format) is georeferenced and the cloudiness (higher and thicker layers) is filtered (eliminated) fully automatically by the algorithms incorporated in the treatment software.

The VISUAL FOX PRO software performs temperature averages every $0.25^{\circ}$ both latitude and longitude, with a second programming process. In this same package, the information corresponding to the daily files (images) is averaged to obtain the daily, weekly, fortnightly or monthly average of the parameter under evaluation. Finally, this georeferenced and averaged information is introduced in a third type of software (SURFFER) with which the SST contour maps are obtained. Regarding this procedure, Sobrino et al. (1996), state that this resource is very useful, because it allows to identify thermal anomalies, comparing the value determined for a weekly time lapse with the historical average in a reference period. 
por el satélite) a Temperatura Superficial del Mar, a partir de la radiantica recibida en los canales $4(10,50 \mu \mathrm{m}$ $11,30 \mu \mathrm{m})$ y $5(11,50 \mu \mathrm{m}-12,50 \mu \mathrm{m})$, donde se captura la radiación emitida por la superficie en el infrarrojo térmico. Posteriormente, la información (ya en formato de SST) es georreferenciada y la nubosidad (estratos altos y más espesos) es filtrada (eliminada) de forma totalmente automática por los algoritmos incorporados en los softwares de tratamiento.

En el software VISUAL FOX PRO se realizan los promedios de temperatura cada $0,25^{\circ}$ tanto de latitud como de longitud, con un segundo proceso de programación, en este mismo paquete se promedia la información correspondiente a los archivos (imágenes) diarios para obtener el promedio diario, semanal, quincenal o mensual del parámetro en evaluación. Finalmente, esta información georreferenciada y promediada se introduce en un tercer software (SURFFER) con el cual se obtienen los mapas de contornos de TSM. Respecto a este procedimiento, Sobrino et al. (1996) afirman que este recurso es de gran utilidad, pues permite identificar anomalías térmicas, comparando el valor determinado para un lapso semanal con el promedio histórico en un período de referencia.

\section{Procesamiento de datos pluviométricos}

Se compilaron y sistematizaron registros de precipitación almacenados en las bases de datos del Instituto Nacional de Meteorología e Hidrología [Inamhi] (2017), correspondientes a 10 estaciones pluviométricas instaladas en la región costera de Ecuador, específicamente, en aquellos sectores donde hubo mayores afectaciones por lluvias extraordinarias o cercanas a ellos. Se analizó el comportamiento de la precipitación media mensual histórica para el período 1998-2016, así como la media anual histórica para el período 1984-2016.

\section{Análisis de calidad de agua}

Para evaluar los efectos de las lluvias sobre los sistemas multipropósito, se analizaron los datos diarios de calidad del agua correspondientes a los últimos cinco años. Esta información fue obtenida en el laboratorio de la Planta de Tratamiento de Agua "Cuatro Esquinas", perteneciente al Sistema Multipropósito Poza Honda, el cual abastece a la población de Portoviejo, capital de la provincia Manabí, como también a otras localidades cercanas. El análisis de parámetros de calidad del agua fue de mucha importancia en este estudio, ya que durante el período estudiado, este

\section{Rainfall data processing}

Precipitation records stored in the databases of the National Institute of Meteorology and Hydrology [INAMHI] (2017) corresponding to 10 pluviometric stations installed in the coastal region of Ecuador were compiled and systematized, specifically for those sectors where there were greater affectations by extraordinary rainfall or near them. The behavior of the historical average monthly precipitation for the 1998-2016 period was analyzed, as well as the historical annual average for the 1984-2016 period.

\section{Water quality analysis}

To assess the effects of rainfall on multipurpose systems, daily water quality data for the last five years were analyzed. This information was obtained in the laboratory of the "Cuatro Esquinas" Water Treatment Plant, belonging to the Poza Honda Multipurpose System, which supplies the population of Portoviejo, capital of the Manabí province, as well as other nearby localities. The analysis of water quality parameters was of great importance in this study, since during the period studied, this service was systematically suspended in some localities, due to the high concentration of sediments in the water, which did not allow its processing, prior to its distribution through the aqueduct system.

\section{Field information gathering}

The information related to the effects of the extraordinary rainfall was collected through in situ observations during 5 field visits, in the sectors of Manta, Portoviejo, Lodana, Calceta and Chone, these being the urban and rural population centers with reports of greater damage, attributed to the event of extraordinary rainfall in February - March 2017. In addition, in order to have a broader spectrum of information and to perform in-depth analyses of other effects of the rains, an informationgathering strategy was established based on 20 unstructured interviews with key informants, through selective sampling, selecting participants according to the context, under the focus of qualitative research. The participants were asked with open, flexible questions, without pre-established categories, aiming at greater adaptation to the purposes of the research and to the characteristics of the subjects, in such a way that, as Vargas-Jiménez (2012) indicates, they would allow the participants the possibility of expressing their experiences.

The informants were selected through a nonprobability sampling of the inhabitants of the province 
servicio fue suspendido sistemáticamente en algunas localidades, debido a la alta concentración de sedimentos en el agua, lo que no permitía su procesamiento, previo a su distribución a través del sistema de acueductos.

\section{Levantamiento de información de campo}

La información relacionada con los efectos de las precipitaciones extraordinarias se recabaron a través de observaciones in situ durante cinco visitas de campo, en los sectores de Manta, Portoviejo, Lodana, Calceta y Chone, por ser los centros poblados urbanos y rurales con registros de mayores daños, atribuidos al evento de lluvias extraordinarias de febrero - marzo 2017.

Adicionalmente, y a los fines de contar con un espectro deinformación másamplioy analizardetalladamente otros efectos de las lluvias, se procedió a establecer una estrategia de levantamiento de información a partir de 20 entrevistas no estructuradas a informantes clave, a través de un muestreo selectivo, seleccionando a los participantes de acuerdo al contexto, bajo el enfoque de la investigación cualitativa. Las mismas se hicieron con preguntas abiertas, flexibles y sin categorías preestablecidas, buscando una mayor adaptación a los fines de la investigación y a las características de los sujetos, de forma tal, que como indica Vargas-Jiménez (2012), permitieran a los participantes la posibilidad de expresar sus experiencias.

Los informantes se seleccionaron a través de un muestreo no probabilístico de los habitantes de la provincia y representantes de organismos gubernamentales, en total 20 informantes de las localidades más afectadas, cuatro por cada una de las siguientes localidades: Manta, Portoviejo, Lodana, Calceta y Chone. Cada uno de los grupos estuvo conformado por un representante de algún organismo gubernamental, y tres miembros residentes permanentes de cada localidad afectados por el evento de inundación ocurrido en la fecha en análisis. Toda la información obtenida fue procesada y organizada, facilitando así llegar a conclusiones, así como proponer alternativas para enfrentar con éxito las consecuencias de futuros eventos de lluvias extraordinarias.

Influencia de la TSM sobre las precipitaciones extremas

Para evidenciar la influencia de la TSM sobre las precipitaciones extremas se correlacionó los montos de dichas variables para enero, febrero y marzo de todos los años con eventos extremos registrados en las últimas dos décadas. Se consideró la TSM del pacifico ecuatorial en el litoral and representatives of government agencies. A total of 20 informants were selected from the most affected localities, four for each one of the following localities: Manta, Portoviejo, Lodana, Calceta and Chone. Each group consisted of a representative of a government agency and three permanent resident members of each locality affected by the flood event at the time of analysis. All the information obtained was processed and organized, and it allowed us to reach conclusions and to propose alternatives through which to successfully deal with the consequences of future extraordinary rainfall events.

\section{Influence of SST on extreme precipitations}

In order to demonstrate the influence of SST on extreme precipitation, the amounts of these variables for January, February and March were correlated with extreme events reported in the last two decades. The SST of the equatorial pacific in the Ecuadorian coast was considered from the images of monthly averages, obtained from the CIIFEEN map generator and the amounts of precipitation of the Portoviejo station, of INAMHI. The correlation was generated with a polynomial function, indicating the trend line and the predictive model.

\section{RESULTS}

Anomalies in the sea surface temperature

Comparisons between SST data revealed deviations of greater than $0.5^{\circ} \mathrm{C}$ from the historical mean, considered thermal anomalies. When these anomalies are positive and persistent in time, in many cases, they cause extraordinary rainfall, as happened in Manabí in the first months of 2017, whose high rainfall records corresponded to coastal areas where thermal anomalies were very evident (Figures 2a, 2b, and 2c).

In general, in the eastern region of the Equatorial Pacific Ocean, warm conditions persisted, manifesting themselves through positive anomalies of between 1 and $3{ }^{\circ} \mathrm{C}$, in areas adjacent to the coasts of Ecuador and Peru. It is important to note that the anomalies reported for the period under consideration remained confined to the coastal region of Peru and Ecuador, giving the name "El Niño Costero" to the phenomenon in Peru. Additionally, the weekly values of the Southern Oscillation Index (IOS) presented values of El Niño conditions from the third week of January. 
ecuatoriano a partir de las imágenes de promedios mensuales, obtenidas del generador de mapas del CIIFEN y los montos de precipitación de la estación Portoviejo, del Inamhi. La correlación se generó con una función polinomial, indicando la línea de tendencia y el modelo predictivo.

\section{RESULTADOS}

\section{Anomalías en la temperatura superficial del mar}

Las comparaciones entre datos de TSM develaron desviaciones superiores a $0,5^{\circ} \mathrm{C}$ respecto a la media histórica, las cuales se consideran como anomalías térmicas. Cuando estas anomalías son positivas y persistentes en el tiempo, en muchos casos, provocan lluvias extraordinarias, tal como ocurrió en Manabí en los primeros meses de 2017, cuyos registros de altos montos de precipitación, se produjeron en sectores costeros donde las anomalías térmicas fueron muy evidentes (Figuras 2a, 2b, y 2c). En líneas generales en la región oriental del océano Pacifico ecuatorial persistieron condiciones

\section{Intertropical Convergence Zone ITCZ}

In mid-2016, the Intertropical Convergence Zone (ITCZ) was located on territories of Central America and, in the last week of December of that same year and early January 2017, the system shifted south, until positioned near the equatorial line (Figure 3). The strong convective activity in the ZCIT propitiated the formation of cloudy systems of great vertical development, causing intense rains on the Ecuadorian coast.

\section{Atmospheric instability in the Amazon}

In the satellite image (Figure 3) captured on January 15, 2017 by the Advanced Baseline Imager (ABI) on GOES16, operated by NOAA and the US National Weather Service, an important cloud belt can be seen along the South American equatorial strip in the Amazon region. This condition also contributed to the precipitation observed in the study area, during which hydrological monitoring indicated that the Chone and Daule rivers were on red alert for overflowing and nine others entered yellow alert status during the first fortnight of February.

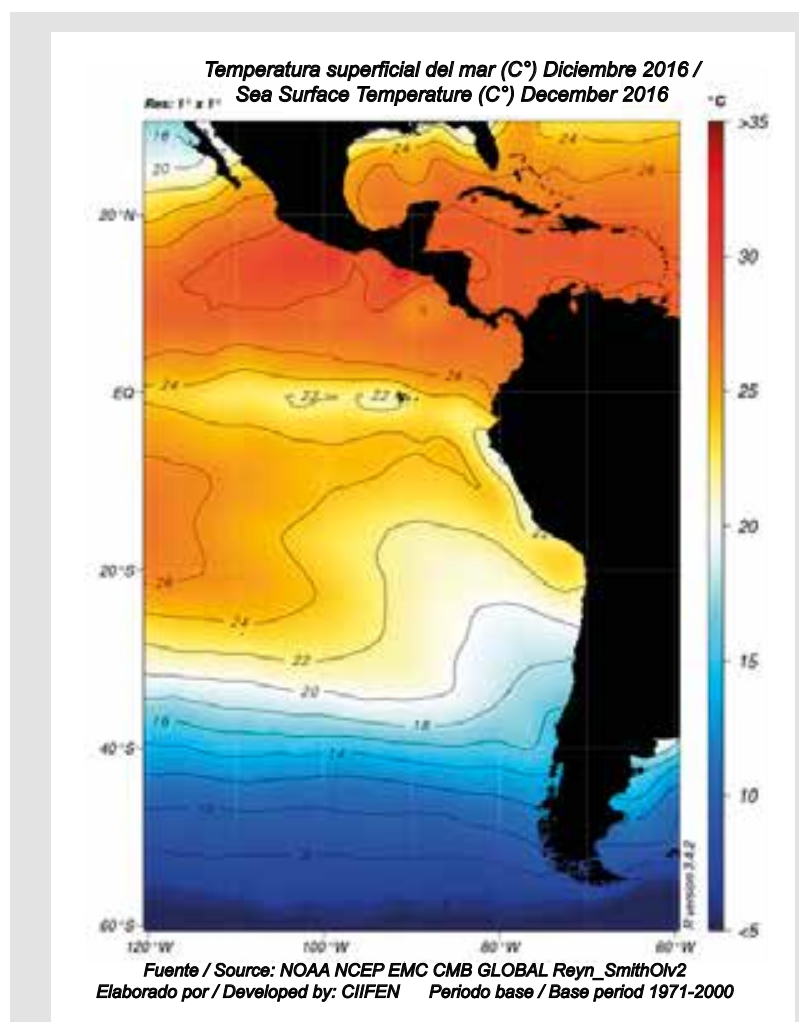

Figura 2a. Temperatura y anomalías térmicas superficiales del mar en aguas del Pacífico ecuatorial para diciembre de 2016. Nótese las fuertes anomalías en la costa de Chile y Perú, así como anomalías medianas en la costa de Guayaquil y Manabí en Ecuador.

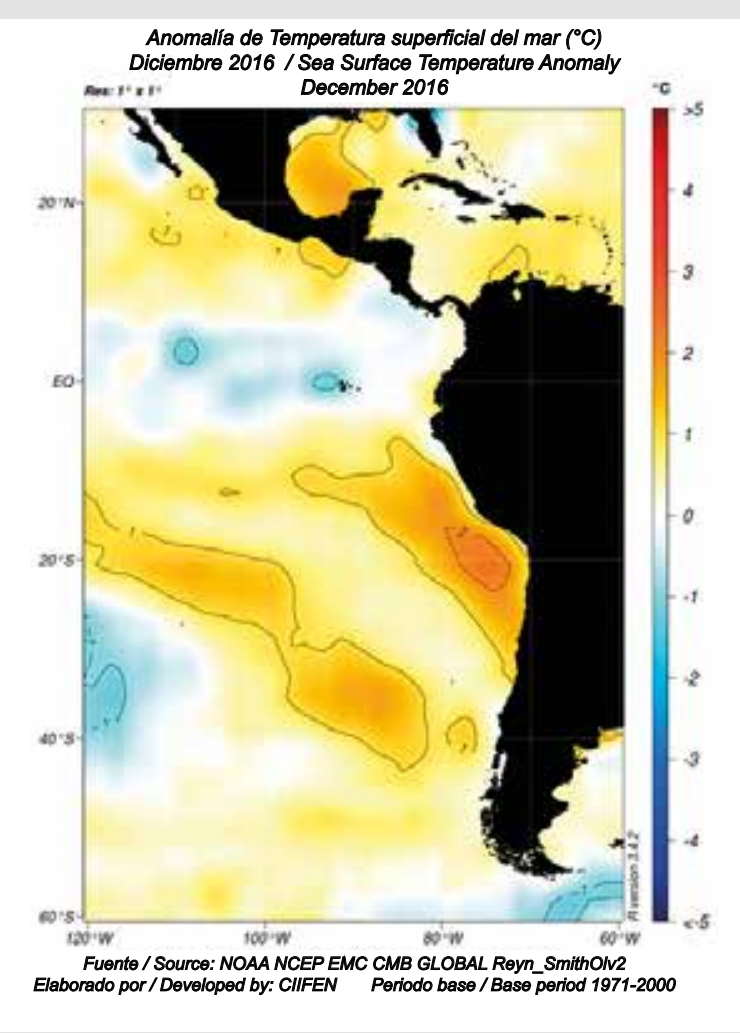

Figure 2a. Sea surface temperature and thermal anomalies in equatorial Pacific waters by December 2016. Note the strong anomalies on the coast of Chile and Peru, and moderate anomalies on the coast of Guayaquil and Manabi in Ecuador. 


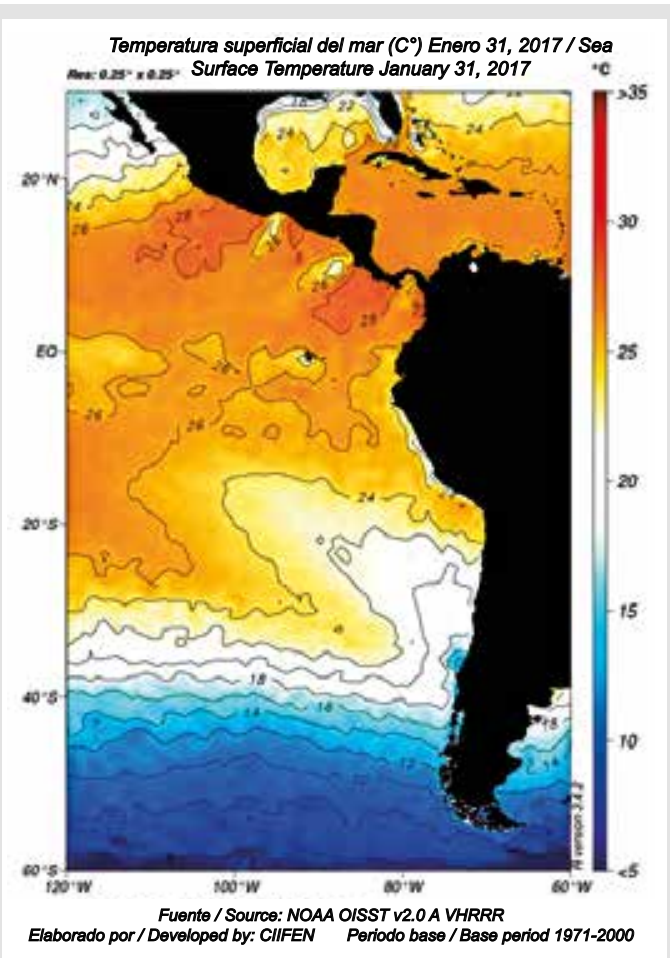

Figura 2b. Temperatura y anomalías térmicas superficiales del mar en aguas del Pacífico ecuatorial para enero de 2017. Se observa la expansión de la anomalía en la costa sur de Ecuador.

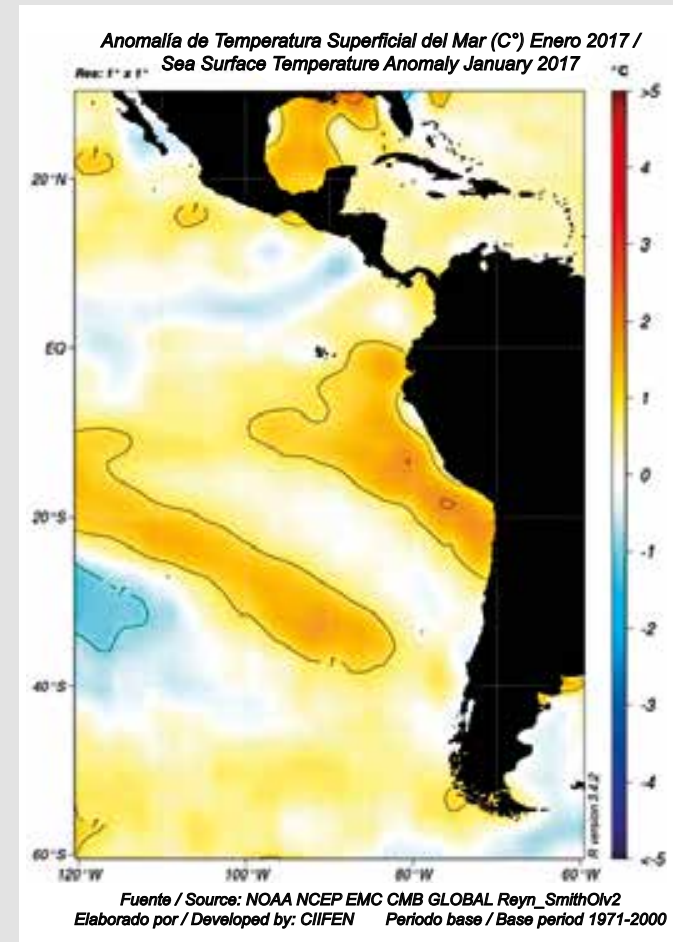

Figure 2b. Sea surface temperature and thermal anomalies in equatorial Pacific waters by January 2017. Expansion of the anomaly is observed on the southern coast of Ecuador.

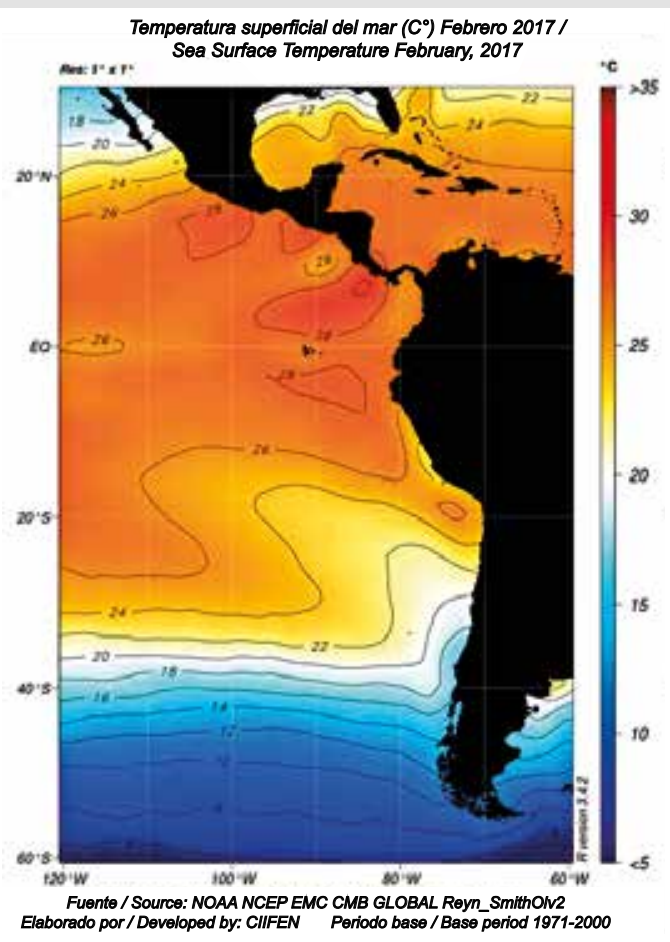

Figura 2c. Temperatura y anomalías térmicas superficiales del mar en aguas del Pacífico ecuatorial para enero de 2017. Se aprecia el notable incremento de la anomalía en la costa norte de Perú y sur del Ecuador.

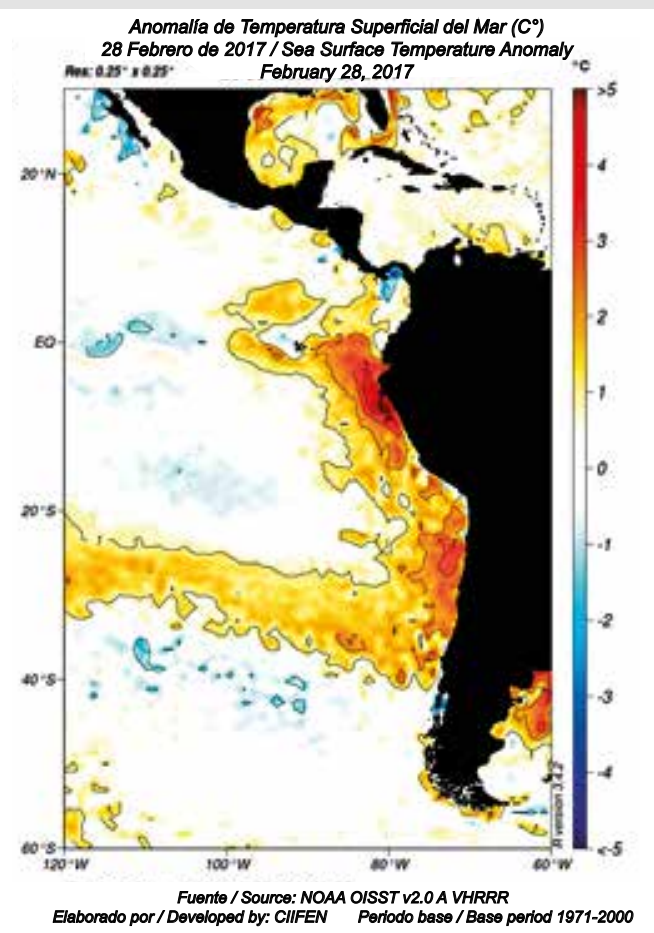

Figure 2c. Sea surface temperature and thermal anomalies in equatorial Pacific waters by January 2017. The remarkable increase of the anomaly can be observed in the north coast of Peru and southern Ecuador. 
cálidas, manifestándose a través de anomalías positivas entre 1 y $3{ }^{\circ} \mathrm{C}$, en áreas adyacentes a las costas de Ecuador y Perú.

Es importante destacar que las anomalías registradas para el período considerado se mantuvieron circunscritas a la región costera de Perú y Ecuador, por lo cual en Perú este fenómeno fue denominado como "El Niño Costero". Adicionalmente, los valores semanales del Índice de Oscilación del Sur (IOS) presentaron valores de condiciones Niño a partir de la tercera semana de enero.

\section{Activación de la Zona de Convergencia Intertropical (ZCIT)}

A mediados de 2016, la Zona de Convergencia Intertropical (ZCIT) se encontraba ubicada sobre territorios de Centroamérica y, en la última semana del mes de diciembre de ese año e inicios de enero de 2017, este sistema experimentó un desplazamiento hacia el sur, hasta posicionarse cerca de la línea equinoccial (Figura 3). La fuerte actividad convectiva en la ZCIT propició la formación de sistemas nubosos de gran desarrollo vertical, ocasionando lluvias intensas al interior del litoral ecuatoriano.

\section{Extraordinary rainfall of 2017}

The maximum intensity of the extraordinary rainfall of 2017 was recorded in Portoviejo (provincial capital) with $81 \mathrm{~mm}$ on February 7 (INAMHI, 2017). The annual rainfall in Portoviejo has historically averaged 602.7 $\mathrm{mm}$, with an annual regime of unimodal type for the entire Ecuadorian coast and $95 \%$ of rainfall concentrated between December and May, highlighting its maximums in February and March (Figure 4).

This pluviometric regime is conditioned by the presence of the Humboldt current on the South American Pacific coast, which decreases the SST, during the second semester of the year on the Ecuadorian Coast and with it the evaporation of the oceanic waters, evidenced in low amounts of precipitation.

\section{Influence of SST on extreme precipitations}

Historical records of precipitation for the Ecuadorian coast (Figure 5) show a striking recurrence of events of extraordinary rains and droughts, distancing significantly from the historical average.

The occurrence of extreme events in the last 20 years on the Ecuadorian coast corresponds to four droughts (1988, 1990, 1991 and 2003) and four extraordinary

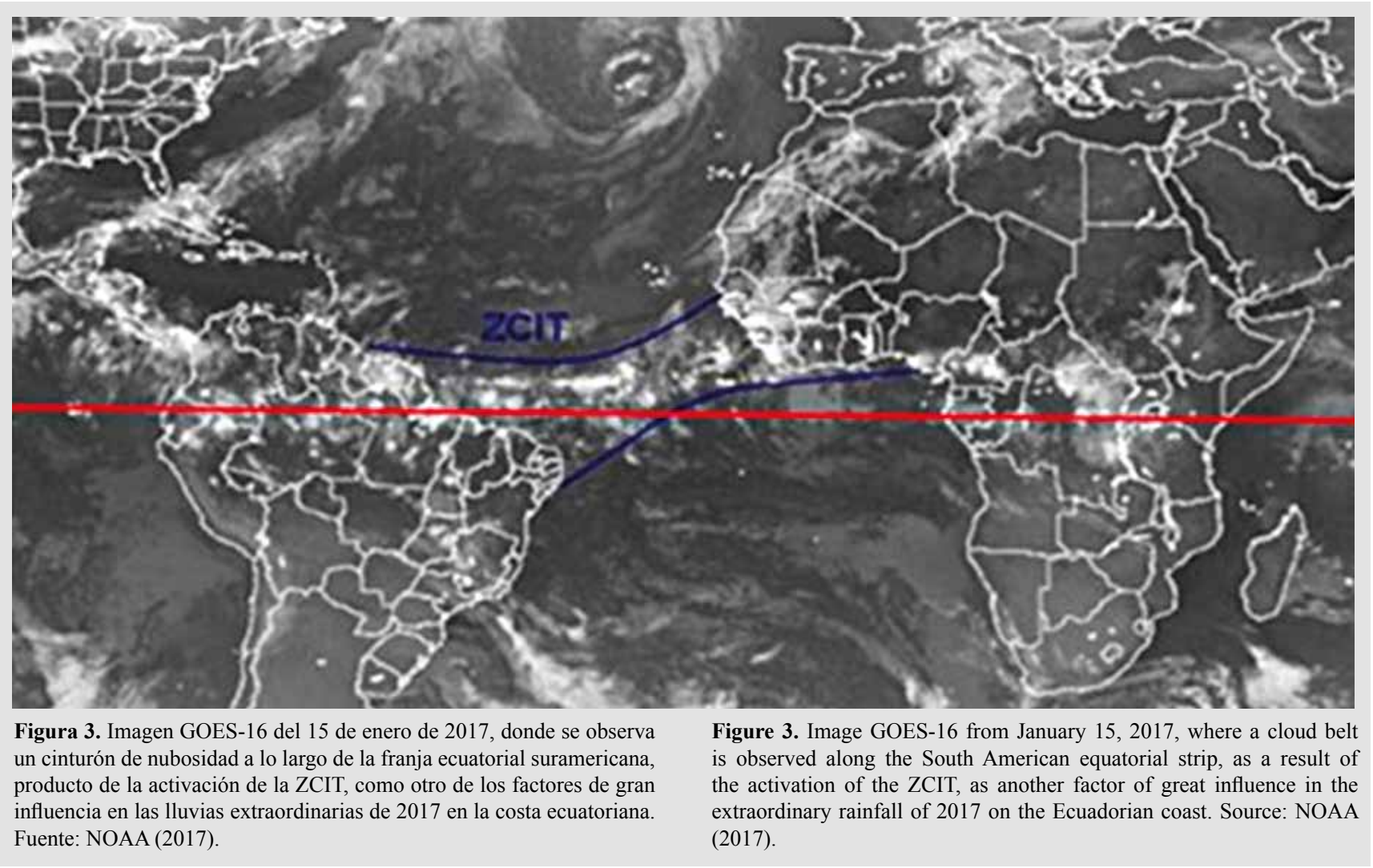




\section{Inestabilidad atmosférica en la Amazonia}

En la imagen satelital (Figura 3), adquirida el 15 de enero de 2017 por el Advanced Baseline Imager (ABI) en el GOES-16, operado por la NOAAy el Servicio Meteorológico Nacional de los EE. UU., se aprecia un importante cinturón de nubosidad a lo largo de la franja ecuatorial suramericana, en la región amazónica. Esta condición también contribuyó con las precipitaciones observadas en el área de estudio, durante las cuales el monitoreo hidrológico indicaba que los ríos Chone y Daule estuvieron en alerta roja por desbordamiento $\mathrm{y}$, otros nueve, entraron en estado de alerta amarilla durante la primera quincena de febrero.

\section{Lluvias extraordinarias de 2017}

La máxima intensidad de estas lluvias extraordinarias de 2017 se registró en Portoviejo (capital provincial) con $81 \mathrm{~mm}$ el 7 de febrero. (INAMHI, 2017). La precipitación anual en la estación Portoviejo alcanza rainfall events (1997, 1998, 2011 and 2017). These extreme events are strongly influenced by variations in SST, reflected as thermal anomalies. The supposition is confirmed that the positive thermal anomalies in the equatorial Pacific positively affect the occurrence of extraordinary rainfall, as shown in Figure 6, where the correlation between SST and extreme precipitation events, reflects a directly proportional behavior, able to explain $72 \%$ of the extraordinary rainfall by SST anomalies. The remaining $28 \%$ of extreme events could be influenced by Intertropical Convergence and atmospheric instability in the Amazon.

\section{DISCUSSION}

Causes of the extraordinary precipitations of 2017 and their implications

The extraordinary magnitudes of early 2017 rainfall records on the Ecuadorian coast were due to the combined effect of positive thermal anomalies in the

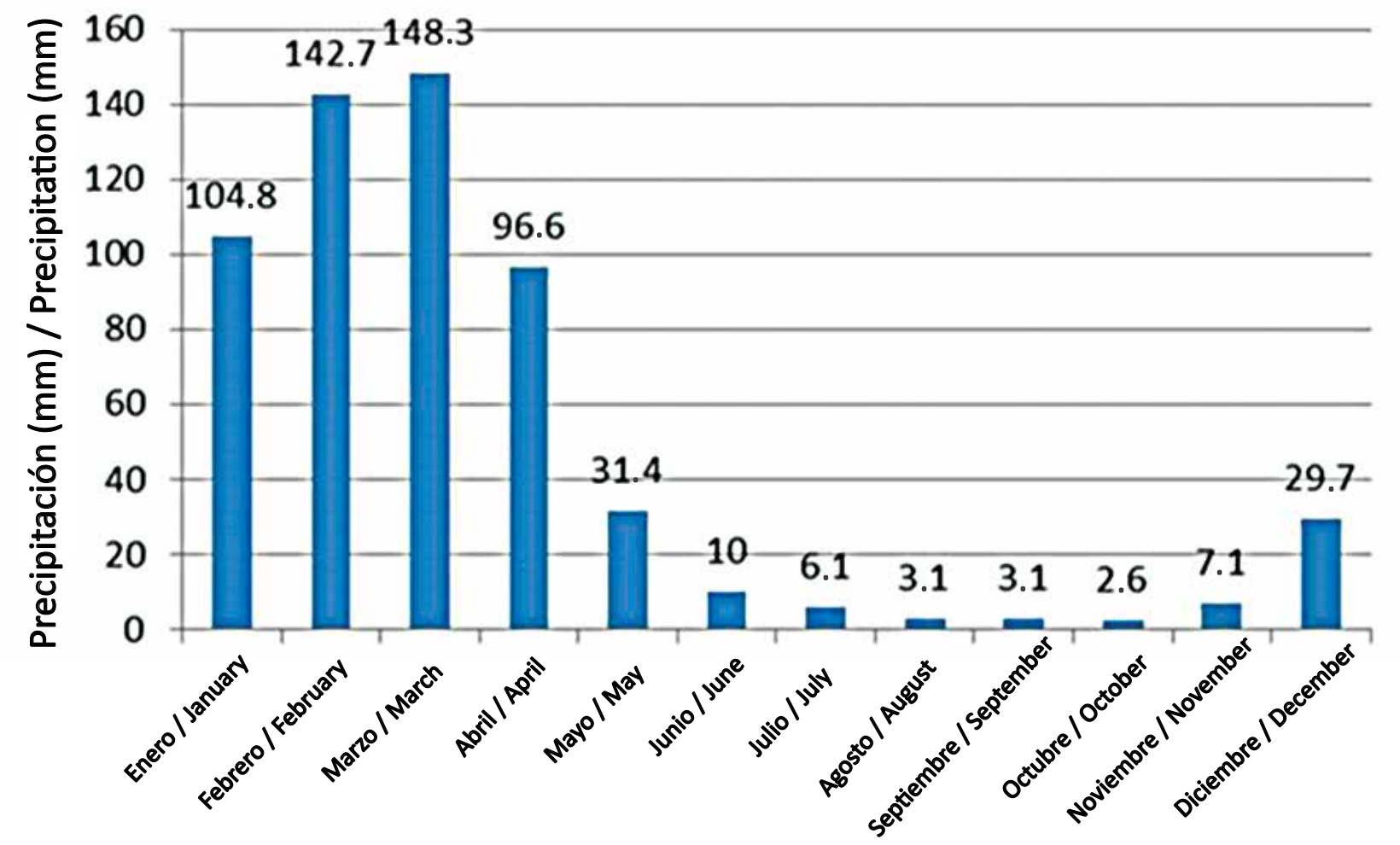

Figura 4. Precipitación media mensual histórica en la estación Portoviejo, período 1998-2016. Fuente: INAMHI (2017). Se evidencia una alta concentración de las precipitaciones durante los primeros cuatro meses del año y la ocurrencia de un importante déficit hídrico en los restantes ocho meses.
Figure 4. Historical average monthly rainfall in Portoviejo station, 19982016 period. Source: INAMHI (2017). There is a high concentration of rainfall during the first four months of the year and the occurrence of a significant water deficit in the remaining eight months. 
históricamente en promedio $602,7 \mathrm{~mm}$, con un régimen anual de tipo unimodal para toda la costa ecuatoriana con $95 \%$ de las lluvias concentradas entre diciembre y mayo, destacando sus máximas en febrero y marzo (figura 4).

Este régimen pluviométrico es condicionado por la presencia de la corriente de Humboldt en la costa Pacífica suramericana, lo que disminuye la TSM durante el segundo semestre del año en la costa ecuatoriana y con ello la evaporación de las aguas oceánicas, evidenciándose en bajos montos de precipitación. equatorial Pacific, the activity of the ZCIT and atmospheric instability in the Amazon.

Thermal anomalies in the equatorial Pacific

The positive thermal anomalies evidenced from the satellite images are closely related to the extraordinary rainfall that occurred in the South American Pacific coast during the first months of 2017, which had disastrous effects in several urban and rural sectors of the province.

The atypical increase or decrease of SST in the central equatorial Pacific is largely responsible for the

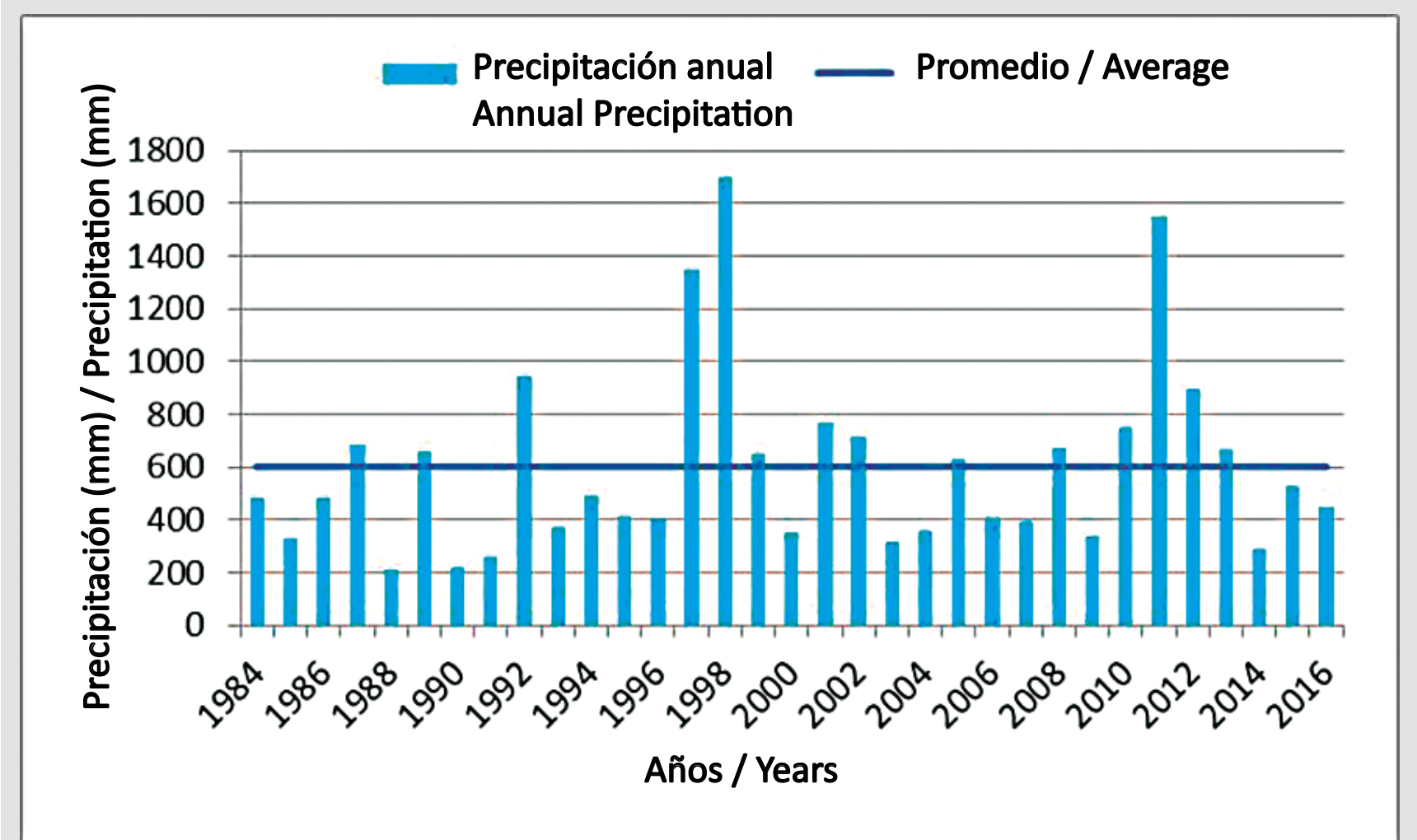

Figura 5. Precipitación media anual histórica en la estación Portoviejo, período 1984-2016. Fuente: INAMHI (2017). La variabilidad interanual registra anomalías positivas y negativas, relacionadas directamente con las manifestaciones de los fenómenos El Niño y La Niña.
Figure 5. Historical annual average rainfall at Portoviejo station, 1984 2016. Source: INAMHI (2017). The inter-annual variability records positive and negative anomalies, directly related to the manifestations of the El Niño and La Niña phenomena.
Influencia de la TSM sobre las precipitaciones extremas

Los registros históricos de precipitaciones para la costa ecuatoriana (Figura 5) muestran una llamativa recurrencia de eventos de lluvias y sequias extraordinarias, distanciándose significativamente del promedio histórico.

La ocurrencia de eventos extremos de los últimos 20 años en la costa ecuatoriana se corresponde variability of the world's climate (Constantino et al., 2011). According to CIIFEN (2017), during the first quarter of 2017, the equatorial coastal Pacific was characterized by a progressive increase in SST that, in mid-February, reached values of up to $3^{\circ} \mathrm{C}$ above normal, off the coasts of northern Chile, Peru and Ecuador. The forecasts of the global SST models for the February-April and March- 
con cuatro sequías $(1988,1990,1991$ y 2003) y cuatro lluvias extraordinarias (1997, 1998, 2011 y 2017). Estos eventos extremos están fuertemente influenciados por las variaciones de la TSM, reflejadas como anomalías térmicas. Se confirma el supuesto que las anomalías térmicas positivas en el Pacífico ecuatorial, inciden positivamente en la ocurrencia de lluvias extraordinarias, según se muestra en la figura 6, donde la correlación entre la TSM y los eventos extremos de precipitación refleja un comportamiento directamente proporcional, pudiendo explicarse $72 \%$ de las lluvias extraordinarias por las anomalías de la TSM. El $28 \%$ restante de los eventos extremos pudiera estar influenciado con la Convergencia Intertropical y la inestabilidad atmosférica en la Amazonía.
May 2017 periods, generated values close to Normal in the central equatorial Pacific sector; while, in a wide sector of the eastern Pacific and next to the coast of South America, particularly in the coast of Ecuador, they presented values above Normal, persisting for more than four weeks.

\section{The Intertropical Convergence Zone}

The ZCIT is a band of low atmospheric pressures with frequent formation of clouds of great vertical development, which cause important precipitations to global scale (Venezuelan Air Force [FAV], 2000) in one region. In this regard, Tiscama (2017) maintains that the circulation of the wind in the low levels of the atmosphere allowed important detachments of humidity coming from the ZCIT

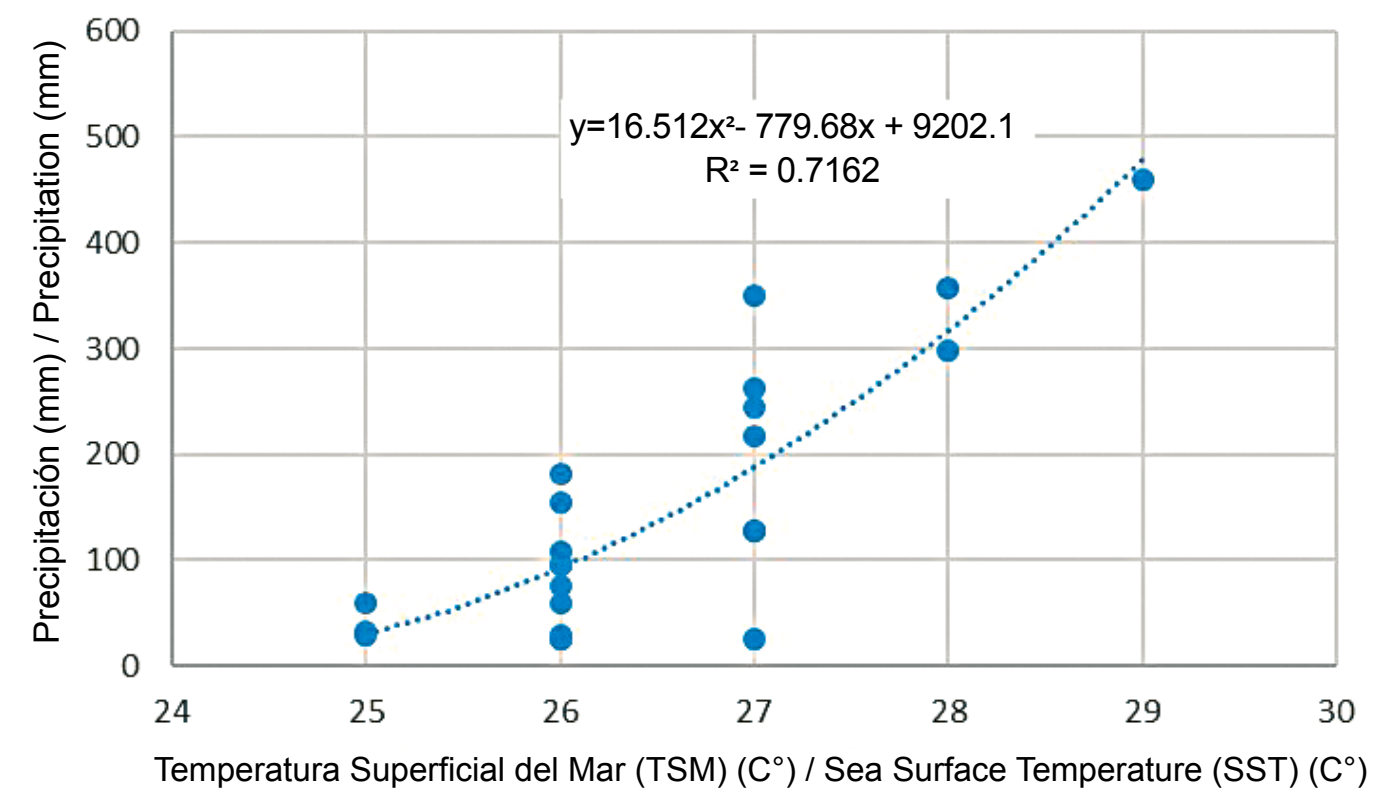

Figura 6. Correlación de los montos de precipitación para eventos extremos con la TSM, de las últimas dos décadas en el litoral ecuatoriano. Fuente de datos: INAMHI y CIIFEEN respectivamente.
Figure 6. Correlation of precipitation amounts for extreme events with the SST for the last two decades on the Ecuadorian coast. Data source: INAMHI and CIIFEEN respectively.

\section{DISCUSIÓN}

Causas de las precipitaciones extraordinarias de 2017 y sus implicaciones

Las magnitudes extraordinarias de los registros pluviométricos de principios de 2017 en la costa ecuatoriana se debieron al efecto combinado de anomalías térmicas positivas en el Pacífico ecuatorial, la actividad de la ZCIT y la inestabilidad atmosférica en la Amazonía. towards the northern part of Ecuador, causing considerable precipitation events, especially in the northern and inland part of the Ecuadorian coast. During the month of January 2017, according to the records of the Instituto Oceanográfico de la Armada [INOCAR] (2017), the long wave radiation in the central Pacific reflected a clear predominance of average air temperature values, higher than normal throughout the country, the most important being those recorded in the coastal region. 
Anomalías térmicas en el Pacífico ecuatorial

Las anomalías térmicas positivas evidenciadas a partir de las imágenes satelitales guardan estrecha relación con las lluvias extraordinarias ocurridas en la costa pacífica suramericana durante los primeros meses de 2017, las cuales, por sus elevados montos, causaron efectos desastrosos en varios sectores urbanos y rurales de la provincia. El incremento o disminución atípica de la TSM en el Pacífico ecuatorial central, es en gran medida responsable de la variabilidad del clima en el mundo (Constantino et al., 2011). De acuerdo con CIIFEN (2017), el Pacífico ecuatorial costero, durante el primer trimestre de 2017, se caracterizó por presentar un incremento progresivo de la TSM que alcanzó, a mediados de febrero, valores de hasta $3^{\circ} \mathrm{C}$ por encima de lo normal, frente a las costas del norte de Chile, Perú y Ecuador.

Las previsiones de los modelos globales de TSM para los períodos febrero-abril y marzo-mayo de 2017 , generaron valores cercanos a la normal en el sector del Pacífico ecuatorial central; mientras que, en un amplio sector del Pacífico oriental y junto a la costa de Suramérica, particularmente en la costa de Ecuador, presentaron valores por encima de lo normal, persistiendo por más de cuatro semanas.

\section{La Zona de Convergencia Intertropical}

La ZCIT es una franja de bajas presiones atmosféricas con frecuente formación de nubes de gran desarrollo vertical, las mismas que ocasionan importantes precipitaciones a escala global (Fuerza Aérea Venezolana [FAV], 2000) en una misma región. Sobre el particular, Tiscama (2017) sostiene que la circulación del viento en los niveles bajos de la atmósfera permitió importantes desprendimientos de humedad procedente de la ZCIT hacia la parte norte del Ecuador, provocando considerables eventos de precipitación, en especial en la parte norte e interior del litoral ecuatoriano. Durante enero de 2017, la radiación de onda larga en el Pacífico central, según los registros del Instituto Oceanográfico de la Armada [INOCAR] (2017), reflejaba un claro predominio de valores medios de temperatura del aire, superiores a las normales en todo el país, siendo los más importantes los registrados en la región litoral.

\section{Inestabilidad atmosférica amazónica}

La influencia de las inestabilidades amazónicas con núcleos convectivos dispersos, fue bloqueada por el

\section{Amazon atmospheric instability}

The influence of Amazonian instabilities with dispersed convective nuclei was blocked by the high subtropical pressure system of the Caribbean. Thus, the precipitations observed to date exceeded the normal monthly ones in the provinces of Esmeraldas, Santo Domingo de los Tsáchilas, north of Manabí and Las Galápagos. In the rest of the coastal region, the values were around or below Normal, as in the case of the peninsula of Santa Elena (INAMHI, 2017).

Historical rainfall behavior and extraordinary events in the study area

Extraordinary rainfall events, basically related to El Niño, occur with certain frequency and are often felt in the same region (Corporación Venezolana de Guayana [CVG], 2000), for example on the Ecuadorian coast. However, these hydrometeorological conditions also occur at different times, with significant economic and material costs and considerable numbers of victims.

Extraordinary events may increase in frequency according to future scenarios modeled by Contreras et al. (2014), Thieelen et al. (2015) and CIIFEN (2017), who state that changes will be gradual and accompanied by an increase in climatic variability and extreme events, which will generate more frequent episodes of droughts and floods, as well as an increase in rainfall intensity. Evidence indicates that such events have already occurred, but they also exist today and probably will in the future, so that catastrophes resulting from them are announced and it is imperative to implement adaptation and mitigation measures.

\section{Extraordinary event of 2017}

Climate phenomena are complex, multifactorial, dynamic and sometimes difficult to predict. The extraordinary event of February 2017 in the Ecuadorian coastal region is convincing evidence of this, as in mid-January forecasts suggested water deficits with the possible presence of the La Niña phenomenon, due to persistent negative thermal anomalies registered in the SST of the equatorial Pacific (NOAA, 2017). However, the situation was totally different than expected, as high volumes of rainfall occurred as a result of atypical heating of the equatorial Pacific in early February, when the temperature reached about $2^{\circ} \mathrm{C}$ above its usual values, with the presence of hot and humid air masses from the Pacific. Such oceanic-atmospheric conditions drastically affected the Ecuadorian coastal region, with 
sistema de altas presiones subtropicales del Caribe. Así, las precipitaciones observadas a la fecha superaron las normales mensuales en las provincias de Esmeraldas, Santo Domingo de los Tsáchilas, norte de Manabí y las Galápagos, mientras que, en el resto de la región litoral, los valores estuvieron alrededor o inferiores a la normal, como en el caso de la península de Santa Elena (Inamhi, 2017).

\section{Comportamiento pluviométrico histórico y eventos} extraordinarios en el área de estudio

Con cierta frecuencia, eventos de lluvias extraordinarias se hacen sentir en una misma región (Corporación Venezolana de Guayana [CVG], 2000), como por ejemplo en la costa ecuatoriana, las cuales básicamente están relacionados con los eventos de El Niño. Sin embargo, estas condiciones hidrometeorológicas también se presentan en momentos distintos a la ocurrencia de aquel fenómeno, cobrando importantes sumas económicas y materiales y considerables cifras de víctimas.

Los eventos extraordinarios pudieran incrementar su frecuencia, de acuerdo con los escenarios futuros modelados por Contreras et al. (2014), Thieelen et al. (2015) y CIIFEN (2017), quienes afirman que los cambios serán graduales y estarán acompañados de un incremento en la variabilidad climática y de eventos extremos, lo que generará episodios más frecuentes de sequías e inundaciones, así como un incremento en la intensidad de las lluvias. Las evidencias indican que este tipo de eventos ya han ocurrido, pero también existen en la actualidad y probablemente en el futuro, con lo cual las catástrofes productos de éstos, son materia anunciada y, se hace perentorio implementar medidas de adaptación y mitigación.

\section{Evento extraordinario de 2017}

Los fenómenos climáticos son complejos, multifactoriales, dinámicos y algunas veces difíciles de pronosticar. El evento extraordinario de febrero de 2017 en la región costera ecuatoriana es una evidencia contundente de ello, pues a mediados de enero los pronósticos sugerían déficits hídricos con la posible presencia del fenómeno La Niña, debido a las persistentes anomalías térmicas negativas registradas en la TSM del Pacífico ecuatorial (NOAA, 2017). Sin embargo, la situación fue totalmente distinta a la esperada, pues se produjeron elevados volúmenes de lluvia como consecuencia de un atípico calentamiento del Pacífico ecuatorial a inicios de febrero, en el que la temperatura alcanzó cerca de $2^{\circ} \mathrm{C}$ por encima de los valores usuales, con pluviometric records that exceeded by far the historical averages in the capital of Manabí (Portoviejo) and other localities of neighboring provinces, reported in this study as the anomaly of the SST affected the entire Ecuadorian coastal region (Table 1).

In sum, the positive anomalies in the SST and the atmosphere were combined, creating conditions for the saturation of humidity and the formation of clouds of great vertical development with electrical activity, which generated extraordinary rainfall concentrated in short periods of time, such as those observed on 7,8 and 17 February 2017, with maximum intensities of $60 \mathrm{~mm} / \mathrm{h}$, according to data from INAMHI (2017) in the PortoviejoUTM station.

The high rainfall was so unusual that intense rains occurred in arid zones, activating channels that had remained inactive for over 20 years, according to the collective memory of the residents. Thus, several localities in the province of Manabí suffered floods and landslides due to soil saturation, overflow of rivers and streams, sewerage collapse, dusting of canals, among other causes. There is no precise explanation for the unusual increase in SST, however, a climatic extreme can be assumed according to the postulates of the Intergovernmental Panel on Climate Change [IPCC] (2007) and, in agreement with Hernández et al. (2013), who affirm that events such as droughts and extreme floods will intensify and increase in frequency.

\section{Field information by key informants}

Information provided by key informants on the extraordinary rainfall of 2017 in Manabí is summarized in Table 2, where two main events are evidenced as triggers of the affectations: the overflowing of rivers, streams and estuaries; and land landslides, which have a very high rate of recurrence. As causes of the event, the interviewees mentioned sedimentation and dusting of the channels and riverbeds, and in the case of the Chone canton, they pointed out problems related to "badly done" work on the riverbed. The main effects were on homes with damage to household goods and appliances, educational centers and flooded roads, as well as lost rice, corn, banana and cocoa crops.

Faced with the situation, key informants reported actions mainly focused on emergency attention, which highlights damage and needs assessment; drainage and cleaning of roads, ducts and canals; delivery of humanitarian aid; and evacuation of housing. With respect to institutional 
presencia de masas de aire cálido y húmedo procedentes del Pacífico. Tales condiciones oceánicas-atmosféricas afectaron drásticamente a la región costera ecuatoriana, con registros pluviométricos que superaron ampliamente los promedios históricos en la capital de Manabí (Portoviejo) y otras localidades de provincias vecinas, que se registran en esta investigación porque la anomalía de la TSM afectó toda la región costera ecuatoriana. (Tabla 1). En síntesis, las anomalías positivas en la TSM y la atmósfera se conjugaron creando condiciones para la saturación de humedad y la formación de nubes de gran desarrollo vertical con actividad eléctrica, lo que generó lluvias extraordinarias concentradas en cortos períodos de tiempo, tal como las observadas los días 7, 8 y 17 de febrero de 2017, con intensidades máximas de $60 \mathrm{~mm} / \mathrm{h}$, según datos del Inamhi (2017) en la estación Portoviejo-UTM.

Tabla 1. Registro de precipitaciones de febrero de 2017 en estaciones de la costa ecuatoriana, comparados con el promedio histórico 19842016 (Inamhi, 2017). Se evidencian incremento máximo de $441 \%$ y un promedio general de $91 \%$. Se presentan registros al sur y norte de la provincia de Manabí, evidenciando que el evento afectó toda la región costera de Ecuador.

\begin{tabular}{|c|c|c|c|c|}
\hline $\begin{array}{l}\text { Provincia } \\
\text { Province }\end{array}$ & $\begin{array}{l}\text { Estación } \\
\text { Station }\end{array}$ & $\begin{array}{c}\text { Precipitación } \\
\text { Normal Feb. }(\mathrm{mm}) \\
\text { Normal Precipitation } \\
\text { Feb. }(\mathrm{mm})\end{array}$ & $\begin{array}{c}\text { Precipitación } \\
\text { Feb. } 2017(\mathrm{~mm}) \\
\text { Precipitation } \\
\text { Feb. } 2017(\mathrm{~mm})\end{array}$ & $\begin{array}{l}\text { Variación (\%) } \\
\text { Variation }(\%)\end{array}$ \\
\hline \multirow[t]{2}{*}{ Manabí } & Manta & 109.1 & 159.5 & 46.2 \\
\hline & Portoviejo & 142.7 & 268.8 & 88.4 \\
\hline Santa Elena & Salinas & 49.6 & 268.7 & 441.7 \\
\hline \multirow[t]{2}{*}{ Guayas } & Guayas & 332.0 & 402.7 & 21.3 \\
\hline & Milagro & 408.1 & 507.9 & 24.5 \\
\hline El Oro & Santa Rosa & 212.0 & 224.1 & 5.7 \\
\hline \multirow[t]{2}{*}{ Santo Domingo } & Santo Domingo & 468.3 & 524,6 & 12.0 \\
\hline & & \multicolumn{2}{|c|}{ Variación Promedio /Average variation } & 91.4 \\
\hline
\end{tabular}

Los altos montos pluviométricos fueron tan inusuales que se presentaron lluvias intensas en zonas áridas, activando cauces que se mantuvieron inactivos por un lapso superior a 20 años, según la memoria colectiva de los pobladores. De tal forma que varias localidades de la provincia Manabí sufrieron inundaciones y deslizamientos de tierra por saturación del suelo, desbordamiento de ríos y quebradas, colapso del alcantarillado, azolve de canales, entre otras causas. No se tiene una explicación precisa del incremento inusual de la TSM; no obstante, se presence, they mentioned the National Risk Secretariat, the Ministry of Social Inclusion and Economy, decentralized governments, the Fire Department, the Ministry of Agriculture and Livestock, and the National Assembly. There is an obvious lack of coordinated risk management processes, and despite this being a frequently recurrent event, according to the perception of key informants, actions focus on emergency attention in post-event operational responses.

In the opinion of the authors of this study, an integrated watershed management process is required, involving the inhabitants of the upper and middle parts. This should include the implementation of sustainable agricultural practices that prioritize soil and forest protection, which would reduce the impact of erosive processes and the magnitude of sedimentation and dusting of rivers and canals.

Table 1. Precipitation record for February 2017 at stations on the Ecuadorian coast, compared to the historical average 1984-2016 (Inamhi, 2017). There was a maximum increase of $441 \%$ and an overall average of $91 \%$. Records are presented to the south and north of the province of Manabí, showing that the event affected the entire coastal region of Ecuador. 
puede presumir un extremo climático de acuerdo con los postulados del Panel Intergubernamental sobre el Cambio Climático [IPCC, por sus siglas en inglés] (2007) y, en concordancia con Hernández et al. (2013) quienes afirman que los eventos como sequías e inundaciones extremas se intensificarán e incrementarán en sus frecuencias.

\section{Información de campo por informantes clave}

Como consecuencia de las lluvias extraordinarias de 2017 en Manabí la información de los informantes clave se resume en la tabla 2, donde se evidencian dos eventos principales como detonantes de las afectaciones, tales eventos fueron el desbordamiento de ríos, quebradas y esteros y los deslizamientos de tierra, mismos que tienen muy alta tasa de recurrencia. Mencionan los entrevistados como causas del evento, la sedimentación y azolvamiento de los canales y cauces de los ríos y en el caso particular del cantón Chone señalaron problemas relacionados con trabajos "mal hechos" en el cauce del río. Las principales afectaciones fueron a viviendas con daños de enseres y electrodomésticos, centros educativos y vialidad inundados, así cultivos de arroz, maíz, plátano y cacao perdidos.

Ante la situación presentada, los informantes clave, registran actuaciones principalmente centradas en la atención de la emergencia, donde destaca evaluación de daños y necesidades, drenaje y limpieza de vías, ductos y canales, entrega de ayuda humanitaria y evacuación de viviendas. Respecto a la presencia institucional, reportan a la Secretaria Nacional de Riesgos, Ministerio de Inclusión Social y Economía, gobiernos descentralizados, Bomberos, Ministerio de Agricultura y Ganadería y Asamblea Nacional.

Se evidencia la ausencia de un proceso coordinado de gestión de riesgos por cuanto, a pesar de ser un evento muy recurrente, según la percepción de los informantes clave, las acciones se centran en la atención de la emergencia en respuestas operativas post evento. Desde la opinión de los autores de la investigación se requiere un proceso de manejo integral de cuencas, involucrando a los habitantes de las partes altas y medias a través de la implementación de prácticas agropecuarias sostenibles que prioricen la protección de bosque y suelos, con lo cual se reduciría el impacto de los procesos erosivos y la sedimentación y azolvamiento de los cauces y canales no se presentarán con la magnitud que actualmente registran los pobladores. rules for reservoirs; and, finally, (c) sediments are the most important natural factor in the pollution of surface waters, which deteriorate the water quality. In short, productive activities, especially when not carried out properly, produce significantly harmful effects on water quality (Ruiz et al. 2017), all of which, according to Valencia et al. (2014), have serious implications for human communities.

The intensity of the rains during the first days of February 2017, reached maximum magnitudes of $40 \mathrm{~mm}$ in 30 minutes $\left(\mathrm{I}_{30}\right)$ (INAMHI, 2017). The high volume of water was captured by an open channel, designed as part of an irrigation system, with a distance of more than $30 \mathrm{~km}$ from the catchment site to the treatment plant. Sediments from the deforested slopes became incorporated as did agrochemical residues, organic plant material, and wastewater from pig and poultry farms, among other effluents. Likewise, the lithology of the study area, formed mainly by very friable and fragile clay shale, favored the addition of numerous pebbles and fine material to the sources of capture, erosive process and transport aided also by the accelerated deforestation of natural vegetation (forest cover) in the province of Manabí which, in recent years, has reached a rate higher than 5000 ha / year (MAE, 2014). This has left a good part of the soil unprotected, helping to increase the volume of sediments added to the water bodies.

In relation to the above, Regües et al. (2017) state that land use is closely related to the variability of infiltration, since soils unprotected by plant cover lead to greater erosion processes. Similarly, Pérez-Viloria and Gónima (2014) point out that the variation of climatic regimes at the local level in the tropics is caused, among other actions, by intense land interventions associated with anthropogenic activities

Ironically, during the rainy season, the drinking water service suffered persistent interruptions in several sectors of Portoviejo. According to information provided by spokespersons of the municipal company, in charge of the city's drinking water, the temporary suspension of the purification treatment and pumping of water in the Cuatro Esquinas plant created a deficit in the availability of drinking water, as its turbidity increased significantly during the intense rainy season, reaching levels that made its treatment impossible, even with the recent installation and testing of a pre-sedimentator.

Under current conditions, the Cuatro Esquinas plant can only treat water with a maximum of 1800 Nephelometric Turbidity Units (NTU). However, there is a new pre-sedimentator that is in its final stage of installation, 
Tabla 2. Resumen sobre las entrevistas a los informantes clave en las poblaciones afectadas.

\begin{tabular}{|c|c|c|c|c|c|}
\hline $\begin{array}{c}\text { Eventos detonantes } \\
\text { Triggering events }\end{array}$ & $\begin{array}{l}\text { Consecuencias } \\
\text { Consequences }\end{array}$ & $\begin{array}{l}\text { Actividades } \\
\text { Avtivities }\end{array}$ & $\begin{array}{c}\text { Instituciones } \\
\text { participantes } \\
\text { Participant } \\
\text { Institutions }\end{array}$ & 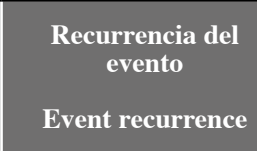 & $\begin{array}{l}\text { Tipo de actuación } \\
\text { Type of action }\end{array}$ \\
\hline $\begin{array}{l}\text { Desbordamiento de } \\
\text { ríos, quebradas y } \\
\text { esteros } \\
\text { Deslizamientos } \\
\text { El principal problema } \\
\text { es el estado de } \\
\text { azolvamiento de los } \\
\text { canales y esteros } \\
\text { Algunos informantes } \\
\text { indican que trabajos } \\
\text { previos en el cauce } \\
\text { del río contribuyen al } \\
\text { desbordamiento }\end{array}$ & $\begin{array}{l}\text { Afectación a viviendas } \\
\text { (daños de enseres y } \\
\text { electrodomésticos), } \\
\text { centros educativos y } \\
\text { vialidad } \\
\text { Inundación de cultivos } \\
\text { arroz, maíz, plátano y } \\
\text { cacao, } \\
\text { Afectaciones en los } \\
\text { sistemas de agua } \\
\text { potable, alcantarillado } \\
\text { y energía eléctrica }\end{array}$ & $\begin{array}{l}\text { Evaluación de daños y } \\
\text { necesidades } \\
\text { Drenaje y limpieza de } \\
\text { vías, ductos y canales } \\
\text { Entrega de ayuda } \\
\text { humanitaria } \\
\text { Evacuación }\end{array}$ & $\begin{array}{l}\text { Secretaria Nacional } \\
\text { de Riesgos, Ministerio } \\
\text { de Inclusión Social y } \\
\text { Economía, Gobiernos } \\
\text { descentralizados, } \\
\text { Bomberos, Ministerio } \\
\text { de Agricultura y } \\
\text { Ganadería, Asamblea } \\
\text { Nacional }\end{array}$ & Muy alta & $\begin{array}{l}\text { Atención de } \\
\text { emergencias }\end{array}$ \\
\hline $\begin{array}{l}\text { Overflowing of rivers, } \\
\text { streams and estuaries } \\
\text { Landslides } \\
\text { The main problem is } \\
\text { the dusting of channels } \\
\text { and estuaries } \\
\text { Some informants } \\
\text { indicate that previous } \\
\text { work on the riverbed } \\
\text { contributes to the } \\
\text { overflow }\end{array}$ & $\begin{array}{l}\text { Impact on housing } \\
\text { (damage to household } \\
\text { goods and appliances), } \\
\text { educational centers and } \\
\text { roads. } \\
\text { Flooding of rice, maize, } \\
\text { banana and cocoa } \\
\text { crops, } \\
\text { Effects on drinking } \\
\text { water, sewerage and } \\
\text { electricity systems }\end{array}$ & $\begin{array}{l}\text { Damage and needs } \\
\text { assessment } \\
\text { Drainage and cleaning } \\
\text { of tracks, ducts and } \\
\text { canals } \\
\text { Delivery of } \\
\text { humanitarian aid } \\
\text { Evacuation }\end{array}$ & $\begin{array}{l}\text { National Risk } \\
\text { Secretariat, Ministry } \\
\text { of Social Inclusion } \\
\text { and Economy, } \\
\text { Decentralized } \\
\text { Governments, } \\
\text { Firefighters, Ministry } \\
\text { of Agriculture and } \\
\text { Livestock, National } \\
\text { Assembly }\end{array}$ & Very High & Emergency care \\
\hline
\end{tabular}

Table 2. Summary of interviews with key informants in affected populations.
Consecuencias de las precipitaciones extraordinarias de 2017

\section{Interrupciones en el servicio de agua potable}

La erosión y el consecuente deterioro de las cuencas hidrográficas se manifiestan como factores limitantes en cualquier plan hidráulico, particularmente por tres razones: (a) una acelerada producción de sedimentos que acorta la vida útil de los embalses y aminora su capacidad de regulación, al tiempo que compromete las demandas de agua; (b) los caudales base $\mathrm{y}$, por consiguiente, las disponibilidades medias, tienden a disminuir y a incrementar las crecidas, afectando la regularidad del ciclo hidrológico y, por ende, las reglas de operación de los embalses; y, por último, (c) los sedimentos son el factor natural más importante en la polución de las aguas superficiales, con lo cual su calidad se ve deteriorada. En definitiva, las actividades productivas, especialmente cuando no se llevan a cabo de manera adecuada, producen efectos significativamente dañinos sobre la calidad del agua (Ruiz et al. 2017), todo lo cual, de acuerdo con Valencia et al. (2014), tiene serias implicaciones sobre las comunidades humanas.

La intensidad de las lluvias durante los primeros días de febrero de 2017 registró magnitudes máximas de $40 \mathrm{~mm}$ to begin with a period of tests and to finally be put into operation in order to increase the water treatment capacity to up to 10000 NTU. However, during the rains of 2017, the turbidity exceeded that figure and reached maximum values of $25000 \mathrm{NTU}$, so the suspension of the water service was one of the marked effects and will undoubtedly continue to be so in future events of similar magnitude.

The correlation between turbidity and precipitation presented in Figure 7 is the strongest evidence of the above statements. During the first days of February, a positive correlation was observed, with a trend adjusted to a $4^{\text {th }}$ order polynomial and a $\mathrm{R}^{2}=0.96$.

Figure 7 shows how turbidity values are kept more or less low and stable with rainfall less than $40 \mathrm{~mm}$ in 24 hours, while rainfall with higher intensities exponentially increases turbidity records, exceeding 10,000 NTU with $70 \mathrm{~mm}$ of precipitation in 24 hours. Understanding this behavior is fundamental in planning the supply of drinking water in Portoviejo, because the prompt completion and commissioning of the new pre-sedimentator at the Cuatro Esquinas plant will increase the treatment capacity to a maximum of 10000 NTU (PORTOAGUAS, 2017). Thus, in rainfall with intensities greater than $70 \mathrm{~mm}$ in $24 \mathrm{~h}$, the 
en 30 minutos $\left(I_{30}\right)$ (Inamhi, 2017), cuyo elevado volumen de agua fue captado por un canal abierto, diseñado como parte de un sistema de riego, con una distancia superior a 30 $\mathrm{km}$ desde el sitio de captación hasta la planta de tratamiento. Durante ese recorrido no sólo se incorporaron sedimentos de las vertientes deforestadas, sino también residuos agroquímicos, material orgánico vegetal, aguas servidas de granjas porcinas y avícolas, entre otros efluentes. Así mismo, la litología del área de estudio, conformada principalmente por lutitas arcillosas muy friables y deleznables, favoreció el aporte de abundantes guijarros y material fino a las fuentes de captación, proceso erosivo y de transporte coadyuvado además, por la deforestación acelerada de la vegetación natural (cubierta boscosa) en la provincia de Manabí que, para los últimos años, ha alcanzado una tasa superior a 5000 ha/año (MAE, 2014). Ello ha dejado sin protección buena parte del suelo, lo que contribuyó a incrementar el volumen de sedimentos aportados a los cuerpos de agua.

Con relación a lo anterior, Regües et al. (2017) manifiestan que el uso de la tierra guarda una estrecha relación con el comportamiento de la variabilidad de la infiltración, pues suelos desprotegidos de cobertura vegetal, conducen a mayores procesos de erosión. De igual manera, señalan Pérez-Viloria y Gónima (2014) que la variación de los regímenes climáticos a nivel local en el trópico, es causada entre otras acciones por intervenciones intensas de la tierra asociadas a actividades antrópicas.

Irónicamente, durante la época de lluvias, el servicio de agua potable sufrió persistentes interrupciones en varios sectores de la ciudad de Portoviejo. De acuerdo con información suministrada por voceros de la empresa municipal, que tiene la competencia del agua potable en la ciudad, la suspensión temporal del tratamiento de potabilización y bombeo de agua en la planta de Cuatro Esquinas, crearon un déficit en la disponibilidad del vital líquido, ya que su turbidez se incrementó significativamente durante la época de lluvias intensas, alcanzando niveles que imposibilitaron su tratamiento, aun con la reciente instalación y puesta en prueba de un pre-sedimentador.

Bajo las condiciones actuales, la planta de Cuatro Esquinas solo tiene posibilidad de tratamiento de agua con un máximo de 1800 Unidades Nefelométricas de Turbidez (NTU, por sus siglas en inglés). No obstante, existe un nuevo pre-sedimentador que se encuentra en su etapa final de instalación, para comenzar con un período de pruebas $\mathrm{y}$, finalmente, entrar en funcionamiento, con el propósito de incrementar la capacidad de tratamiento de aguas hasta plant will have to suspend water treatment, resulting in an inevitable deficit in the city's water distribution and supply.

\section{Floods in urban and rural sectors}

Several sectors of Manabí continued to be flooded for several days, due to the rain storm that was recorded as being stronger on February 7 and 8, 2017, when the water from the heavy rains collapsed the sewage system and irrigation channels, which had been affected by the earthquake of April 16, 2016 (MAGAP, 2016; Senplades, 2016). Among the affected rural communities in the Tosagua canton are Los Corrales, Las Guaijas, Los Pachones, La Poza and La Madera, which are mainly dedicated to shortcycle crops, including rice. In the urban area, the following sites were flooded: Divino Niño, San Pedro, San Roque Bajo, Humberto González, Malecón 1 and 4 and Las Balsas, among other citadels.

As a result of the rains, the Risk Management Secretariat (2017) quantified some 627 families affected by the storm, 400 of which had to be evacuated. One interviewee pointed out that due to the intense rains, the estuaries of El Muerto, Mojinal, Montañita, Las Botijas and Achiote grew, which together formed a "great delta (mouth of a great river)" that even dammed the Carrizal River. The same interviewee maintained that many were affected by these floods and, textually expressed "...if this heavy rain continues as predicted, we are going to continue to be affected..."

The extraordinary precipitations generated floods and sedimentation in rural and urban areas, where in many cases, the need to carry out preventive activities had already been pointed out, and ignored, leading to loss of human lives, goods and services, as well as environmental assets. Official figures from the National Secretariat of Risks indicate about 150000 affected, 8000 ha of damaged crops and more than $1000 \mathrm{~km}$ of affected roads. These are just some of the alarming figures that show the need for further research related to this issue, as well as its socialization with communities and government authorities, in order to undertake preventive, mitigating and remedial activities against the impacts of a natural phenomenon that will undoubtedly continue to occur and even more intensely.

\section{Subsurface erosion and sinkholes}

One of the little visible effects of the extraordinary rainfall, particularly in the city of Portoviejo, is the erosion caused by subsurface runoff under the road network. 
con 10000 NTU; sin embargo, durante las lluvias de 2017 la turbidez superó esa cifra y alcanzó valores máximos de 25000 NTU, por lo cual la suspensión eventual del servicio de agua fue uno de los efectos marcados y, seguramente, lo seguirá siendo en futuros eventos de similar magnitud.

La correlación entre la turbidez y la precipitación presentada en la figura 7 es la evidencia más contundente de las afirmaciones anteriores. Durante los primeros días de febrero se observó una correlación positiva, con una tendencia ajustada a un polinomio de $4^{\text {to }}$ orden y un $\mathrm{R}^{2}=0,96$.

La Figura 7 muestra como los valores de turbidez se mantienen más o menos bajos y estables con lluvias inferiores a $40 \mathrm{~mm}$ en $24 \mathrm{~h}$, mientras que las lluvias con intensidades superiores incrementan exponencialmente los registros de turbidez, superando los 10.000 NTU con $70 \mathrm{~mm}$ de precipitación en $24 \mathrm{~h}$. Comprender este comportamiento es fundamental para la planificación del suministro de agua potable en la ciudad de Portoviejo, debido a que la pronta culminación y puesta en funcionamiento del nuevo presedimentador en la planta de Cuatro Esquinas incrementará
Some of the city's rainwater collectors were affected by the earthquake of April 16, 2016 (Pacheco, 2017), causing progressive infiltrations that, in some cases, resulted in the re-emergence of water through sewage systems and other road infrastructure. The abrupt increase in the flows generated by the extraordinary rainfall heightened the effects of the earthquake and the erosive power of the water caused greater ruptures in the concrete collectors, which gradually created tunnel-like voids under the roads. These processes of subsurface erosion are known as sofussion.

Some of these voids eventually collapsed, creating holes known in popular jargon as socavones (sinkholes), with maximum dimensions of $5 \mathrm{~m}$ long by $3 \mathrm{~m}$ wide, some of them, with extended damage along the pipe of up to 80 $\mathrm{m}$, detected by robotic cameras that penetrate the ducts and emit images of the state of the pipes.

The eight sinkholes caused strong congestion in the automotive traffic, due to the forced closure of roads with repair costs that, according to technical information from the management of Portoaguas, the company in charge

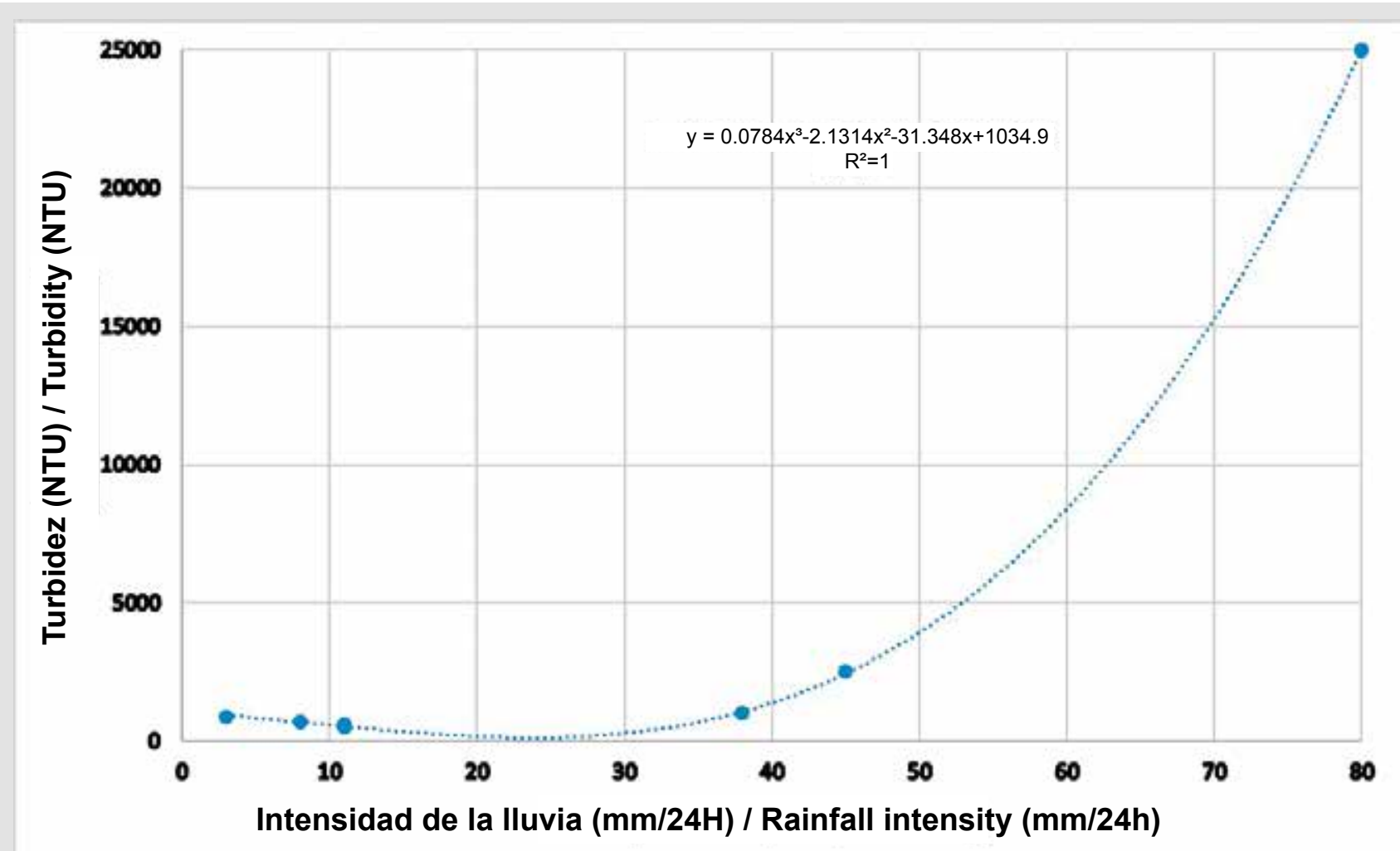

Figura 7. Correlación entre la intensidad de la lluvia en 24 horas y la turbidez del agua del río. Se observa un incremento exponencial en la turbidez del agua del río con lluvias de intensidad superior a $50 \mathrm{~mm}$ en 24 horas. Datos de los primeros nueve días de febrero de 2017. Fuente: Inamhi (2017) y Portoaguas (2017).
Figure 7. Correlation between the intensity of the rain in 24 hours and the turbidity of the river water. There is an exponential increase in the turbidity of the river water with rainfall of more than $50 \mathrm{~mm}$ in 24 hours. Data for the first nine days of February 2017. Source: Inamhi (2017) and Portoaguas (2017). 
la capacidad de tratamiento hasta un máximo de 10000 NTU (Portoaguas, 2017); por lo tanto, en presencia de lluvias con intensidades superiores a los $70 \mathrm{~mm}$ en 24 horas, la planta deberá suspender el tratamiento del líquido, lo que se traducirá en un inevitable déficit en la distribución y abastecimiento de agua en la ciudad.

\section{Inundaciones en sectores urbanos y rurales}

Varios sectores de Manabí continuaron anegados por muchos días, debido al temporal lluvioso que se registró con mayor fuerza durante los días 7 y 8 de febrero de 2017, cuando el agua de las precipitaciones de gran intensidad colapsó el sistema de alcantarillado y de canales de riego, mismos que habían quedado afectados por el sismo del 16 abril de 2016 (MAGAP, 2016; Senplades, 2016). Entre las comunidades rurales afectadas del cantón Tosagua están Los Corrales, Las Guaijas, Los Pachones, La Poza y La Madera, las cuales se dedican principalmente a realizar cultivos de ciclo corto, entre ellos arroz. Mientras que en el área urbana resultaron inundados los sitios Divino Niño, San Pedro, San Roque Bajo, Humberto González, Malecón 1 y 4 y Las Balsas, entre otras ciudadelas.

Producto de las mismas lluvias, la Secretaría de Gestión de Riesgos (2017) cuantificó unas 627 familias perjudicadas por el temporal, debiendo ser evacuadas 400 de éstas. Adicionalmente, un entrevistado señaló que, debido a las intensas lluvias, crecieron los esteros El Muerto, Mojinal, Montañita, Las Botijas y Achiote, los cuales en su conjunto formaron un "gran delta (desembocadura de un gran río)" que incluso represó al río Carrizal. El mismo entrevistado sostuvo que hubo muchos afectados por estas crecientes $\mathrm{y}$, textualmente expresó “....si continúa como se ha pronosticado, esta lluvia fuerte, vamos a seguir con las afectaciones...".

Las precipitaciones extraordinarias generaron inundaciones y sedimentación en áreas rurales y urbanas, donde en muchos casos, ya se había señalado la necesidad de ejecutar actividades preventivas que fueron ignoradas, conllevando a pérdidas de vidas humanas, bienes y servicios, así como activos ambientales. Cifras oficiales de la Secretaria Nacional de Riesgos indican cerca de 150000 afectados, 8000 ha de cultivos dañados y más de $1000 \mathrm{~km}$ de vialidad afectada. Estas, son solo algunas de las cifras alarmantes que ponen en evidencia la necesidad de profundizar en investigaciones relacionadas con esta temática, así como su socialización con las comunidades y autoridades gubernamentales, a los fines de emprender actividades preventivas, mitigantes y remediales, frente a los impactos de un fenómeno natural que, con toda seguridad, seguirá ocurriendo e incluso con mayor intensidad. of operation and maintenance of the water system, exceed 110000 dollars. The erosive processes and their consequent collapses continued occurring and, by December 2017, there were already 15 sinkholes in the center of the capital Manabita.

\section{Implications for health}

According to information provided by the health personnel at the Verdi Cevallos Balda hospital, in Portoviejo, with the arrival of the rainy season, three types of conditions become recurrent, typified as respiratory infections, gastrointestinal infections and viruses transmitted by biological vectors (mainly mosquitoes), the most frequent being dengue, Zika and chikungunya. Records of patient care for this type of disease in Verdi Cevallos show significant increases with the arrival of rains (determining ecological conditions suitable for the proliferation of transmitting vectors), going from 1949 patients in December 2016 to 2334 in January 2017, representing an increase of 20\%.

\section{CONCLUSIONS AND RECOMMENDATIONS}

Extraordinary rainfall is a phenomenon of complex and multifactorial origin, which is periodically manifested in certain sectors of Ecuadorian geography, especially on the Pacific coast.

For the intense rains in early 2017 on the Ecuadorian coast, several factors were combined, including the anomalous increase in the SST of the equatorial Pacific, the southward displacement of the ZCIT and atmospheric instabilities in the Amazon region.

Positive thermal anomalies in the equatorial Pacific positively affect the occurrence of extraordinary rainfall.

The consequences were felt in the urban and rural sectors with figures indicating about 150000 affected inhabitants, 8000 ha of lost crops and more than $1000 \mathrm{~km}$ of damaged roads.

As a first preventive action, consideration should be given to the possibility of issuing forecasts and early warnings, making effective use of satellite-supported technologies to record atmospheric and oceanographic conditions.

In order to complement the satellite records, the network of terrestrial meteorological stations should be upgraded and extended to allow better control, monitoring and follow-up of rainfall on the territory, at local and regional scales. 
Erosión subsuperficial y socavones

Uno de los efectos poco visibles de las lluvias extraordinarias, particularmente en la ciudad de Portoviejo, es la erosión por escorrentía subsuperficial debajo del trazado de la vialidad. Algunos de los colectores de las aguas de lluvia de la ciudad fueron afectados por el terremoto del 16 de abril de 2016 (Pacheco, 2017), causando infiltraciones progresivas que, en ciertos casos, resultaron en la resurgencia de agua por los sistemas de alcantarillado y otras infraestructuras viales. $\mathrm{El}$ incremento brusco de los caudales generados por las lluvias extraordinarias, potenció los efectos del sismo y, el poder erosivo del agua causó roturas mayores en los colectores de hormigón, con lo cual, de manera paulatina, se fueron creando vacíos tipo túneles bajo la vialidad. Estos procesos de erosión subsuperficial son conocidos como sofusión.

Eventualmente, algunos de estos vacíos colapsaron, creando huecos conocidos en la jerga popular como socavones, con dimensiones de máximas de $5 \mathrm{~m}$ de largo por $3 \mathrm{~m}$ de ancho, algunos de ellos, con daños prolongados a lo largo de la tubería hasta por segmentos de $80 \mathrm{~m}$, detectados por cámaras robóticas que penetran en los ductos y emitieron imágenes del estado de las tuberías. Los socavones causaron fuertes congestionamientos en el tráfico automotor, debido al cierre obligado de vías con costos de reparación que, según información técnica de la gerencia de Portoaguas, empresa encargada de operación y mantenimiento del sistema de aguas, sobrepasan los 110000 dólares para las mejoras de los daños causados por los ocho socavones, mientras que estos procesos erosivos y sus consecuentes colapsos continuaron ocurriendo y, hasta diciembre de 2017 , ya se contabilizaban 15 socavones en el centro de la capital manabita.

\section{Afectaciones a la salud}

De acuerdo con información suministrada por el personal de salud del hospital Verdi Cevallos Balda, localizado en Portoviejo, con la llegada de la temporada de lluvias se hacen recurrentes tres tipos de afecciones, tipificadas como infecciones respiratorias, gastrointestinales $\mathrm{y}$ virus transmitidos por vectores biológicos (principalmente mosquitos), siendo los más frecuentes, dengue, zika y chikunguña. Los registros de atención de pacientes por este tipo de enfermedades en el Verdi Cevallos muestran incrementos significativos con la llegada de las lluvias (determinan condiciones ecológicas aptas para la proliferación de los vectores transmisores), pasando de 1949 pacientes en diciembre de 2016 a 2334 en enero de 2017, lo cual representa un incremento de $20 \%$.
Training for agricultural producers is recommended in order to incorporate more environmentally friendly production technologies and to encourage the reduction of greenhouse gas emissions, for example by reducing the use of agrochemicals.

It is beneficial to consider public policies such as the payment of ecosystem services, with a view to implementing actions to protect and conserve forests, soils, and water. 


\section{CONCLUSIONES Y RECOMENDACIONES}

Las lluvias extraordinarias se constituyen como un fenómeno de origen complejo y multifactorial, que se pone de manifiesto de forma periódica en determinados sectores de la geografía ecuatoriana, especialmente en la costa del Pacífico.

Para las lluvias intensas de principios de 2017 en la costa ecuatoriana se conjugaron varios factores, entre ellos el incremento anómalo de las TSM del Pacífico ecuatorial, el desplazamiento hacia el sur de la ZCIT y las inestabilidades atmosféricas en la región amazónica.

Las anomalías térmicas positivas en el Pacífico ecuatorial inciden positivamente en la ocurrencia de lluvias extraordinarias

Las consecuencias se sintieron en los sectores urbanos y rurales con cifras que indican cerca de 150000 habitantes afectados, 8000 ha de cultivos perdidas y más de $1000 \mathrm{~km}$ de vialidad dañada.

Como primera acción preventiva debe considerarse la posibilidad de emitir pronósticos y alertas tempranas, haciendo uso efectivo de las tecnologías soportadas en satélites para los registros de las condiciones atmosféricas y oceanográficas.

Para complementar los registros satelitales debe repotenciarse y ampliar la red de estaciones meteorológicas terrestres, que permita un mejor control, monitoreo y seguimiento de las precipitaciones sobre el territorio, a escala local y regional.

Se recomienda desarrollar acciones de capacitación a los productores agropecuarios, para incorporar tecnologías de producción más amigables con el ambiente e, incentivar la reducción de emisiones de gases de efecto de invernadero, por ejemplo, la disminución del uso de agroquímicos

Es beneficioso considerar políticas públicas como el pago de servicios ecosistémicos, con miras a implementar acciones de protección y conservación de bosques, suelos y agua.

\section{BIBLIOGRAFÍA / LITERATURE CITED}

Aguirre, M., y M. Chávez. 2009. Susceptibilidad al deslizamiento de los suelos y rocas, provincia de Manabí, Ecuador. Tesis de Grado Facultad de Ingeniería en Ciencias de la Tierra, Escuela Superior Politécnica Litoral.

Banco Central del Ecuador. Estadísticas económicas. Quito, Ecuador: Banco Central del Ecuador; 2014. Available: http://anda.inec.gob.ec/anda/index.php/ catalog/270 18/02/2016

Cañon, M. (s.f.) Análisis de la temperatura superficial del Mar (TSM) a partir de imágenes NOAA/AVHRR para el Caribe colombiano entre los 70 $30^{\prime}-$ $78^{\circ} 30^{\prime}$ W y $14^{\circ} 30^{\prime}$ y $7^{\circ} 30^{\prime}$ N. Centro de Investigaciones Oceanográficas e Hidrográficas. CIOH - Escuela Naval - Cartagena. 
CIIFEN (Centro Internacional de Investigaciones del Fenómeno El Niño). 2017. Pronóstico_Estacional_Oeste_y_Sur_de_Sudamerica_OND_2017.http:// crc-osa.ciifen.org/index.php?option=com_content \&view=article\&id=247\&Itemid=671 10/2017

Constantino, L., M.Z. Gil, A. Jaramillo, P. Benavides y A. Bustillo. 2011. Efecto del cambio y la variabilidad climática en la dinámica de infestación de la broca del café, Hypothenemus hampei en la zona central cafetera de Colombia. Libro de Memorias XXXVIII Congreso Sociedad Colombiana de Entomología SOCOLEN, Manizales. 106 p.

Contreras, M., J. Cevallos, T. Erazo, M. González y C. Mizobe. 2014. Cambio y variabilidad climática contemporáneos en la costa de Manabí, Ecuador. Rev. La Técnica., 13: 90-99.

CRED. 2004. The OFDA/CRED Internacional Disaster Database Université Catholique de Louvain-Brussels-Belgium (www.em-dat.net: 15/03/2005).

CVG (Corporación Venezolana de Guayana). 2000. Situación meteorológica generadora de las inundaciones y flujos de lodo en el norte-centro de Venezuela, con especial énfasis en la costa norte. Informe preparado por la Empresa de Electrificación del Caroní (EDELCA). 16 p.

FAO (Food and Agriculture Organization). s/f. En tierra segura desastres naturales y tenencia de la tierra. Recuperado de: http://www.fao.org/docrep/013/ i1255b/i1255b02.pdf.

FAV (Fuerza Aérea Venezolana). 2000. Análisis de las situaciones meteorológicas que afectaron al área norte costera del país durante el mes de diciembre del año 1999. Informe preparado por el Servicio de Meteorología de la Fuerza Aérea de Venezuela. 10 p.

García, F. e I. Cruz. 2009. Variabilidad de la precipitación pluvial en la región Pacífico Norte de México. Agrociencia, 43:1-9.

Gelcer, E., C. Zotarellic, L. Stevensd, F. Perondia, D. Barretoa, D. Maliaf, H. Ecolef, C. Montonea and J. Southworthg. 2018. Influence of El Niño-Southern oscillation (ENSO) on agroclimatic zoning for tomato in Mozambique. Agr. Forest Met., 248:316-328.

Hernández, M., A. González, M. Ramírez y J. Bracho. 2013. Proyecciones climáticas para el estado de Coahuila usando el modelo precs bajo dos escenarios de emisiones. Agrociencia, 47:523-537.

IGM (Instituto Geográfico Militar) 2017. Modelo Digital de Elevaciones. Instituto Geográfico Militar. Quito, Ecuador. Información Geográfica. 2017. Available: http://www.geoportaligm.gob.ec/portal/index.php/sismo-2016/ 13/07/2019

Inamhi (Instituto Nacional de Meteorología e Hidrología). 2017. Anuarios Meteorológicos 1991-2012. Instituto Nacional de Meteorología. Quito, Ecuador, $149 \mathrm{p}$

INEC (Instituto Nacional de Estadística y Censos). 2010. Censo de población y vivienda [internet]. Quito, Ecuador: Instituto Nacional de Estadísticas y Censos; 2010.Available: http://anda.inec.gob.ec/anda/index.php/catalog/270 16/01/2016

INEC (Instituto Nacional de Estadística y Censos). 2012. División Político Administrativa del Ecuador. Quito, Ecuador: Instituto Nacional de Estadísticas y Censos; 2012. Available: http://anda.inec.gob.ec/anda/index.php/catalog/270 16/01/2016

INOCAR (Instituto Oceanográfico de la Armada). 2017. Eventos en el Ecuador. [online] Inocar.mil.ec. Recuperado de http://www.inocar.mil.ec/web/index. php/que-son-los-tsunamis/73-eventos-en-el-ecuador.

IPCC (Intergovernmental Panel on Climate Change). 2007. Cambio climático: Base de ciencia física. Contribución del Grupo de Trabajo I al cuarto informe de evaluación del IPCC. Cambridge University Press, Cambridge Reino Unido y Nueva York, EEUU. 139 p.

MAE (Ministerio del Ambiente de Ecuador). 2011. Informe de la Segunda Comunicación Nacional sobre Cambio Climático. Programa de las Naciones Unidas para el Desarrollo (PNUD).

MAE (Ministerio del Ambiente de Ecuador). 2014. Mapa histórico de la deforestación del Ecuador continental. Ministerio del Ambiente del Ecuador. Quito, Ecuador, $46 \mathrm{p}$.

MAGAP (Ministerio de Agricultura, Ganadería Acuacultura y Pesca). 2016. Desastre Natural 2016. Estado situacional. Manabí-Esmeraldas. Informe Técnico. Coordinación General del sistema de Información Nacional.

Monteros, A. y S. Salvador. 2015. Rendimientos de maíz duro seco en el Ecuador, invierno 2015. Quito, Ecuador: Ministerio de Agricultura, Ganadería, Acuacultura y Pesca.

NOAA (Administración Nacional de Aeronáutica y Espacio). 2017. Registros de temperatura Superficial del Mar en aguas del Pacificó Ecuatorial. http:// www.cpc.ncep.noaa.gov/products/analysis_monitoring/lanina/enso_evolutionstatus-fcsts-web.pdf].

OPS (Organización Panamericana de la Salud). 2000. Impacto de los desastres en la salud pública. Editor Erick Noji; Bogotá. 475 p.

Ortiz, C. 2000. Y el Ávila bajó al mar: testimonios y fotografías de la tragedia de Vargas. Caracas: Editorial CEC, S.A., Caracas. 123 p.

Portoaguas. 2017. Informe de Gestión 2017. https://www.epmapap.gob.ec/index.php/transparencia/informe-gestion

Pacheco, H. 2017. Efectos del sismo del 16 de abril de 2016 en el sector productivo agropecuario de Manabí. Rev. La Técnica, 17: 30-42.

Pérez, C.A. 1983. Precipitaciones extraordinarias en España peninsular. Agric. Soc., 28:189-203.

Pérez-Viloria, M. y L. Gónima. 2014. El contenido del vapor de agua de la atmósfera como indicador del calentamiento global en una zona del Caribe de Colombia. Cuad. Invest. Geogr., 40(2), 477-496. Recuperado de http://aeclim.org/wp-content/uploads/2016/02/0018_PU-SA-IX-2014-L_GONIMA.pdf.

Regües, D., D. Badía, M. Echeverría, M. Gispert, N. Lana-Renault, J. León, E. Nadal-Romero, G. Pardini, and P. Serrano-Muela. 2017. Analyzing the effect of land use and vegetation cover on soil infiltration in three contrasting environments in northeast Spain. Cuad. Invest. Geogr., 43(1): 141-169. DOI: 10.18172/cig.3164. 
Ruiz, D. M., J. P. Martínez I., J. D. Otero S. and A. Figueroa C. 2017. Effects of productive activities on the water quality for human consumption in an Andean basin, a case study. Rev. Internal Cont. Amb., 33(3): 361-375. DOI: 10.20937/RICA.2017-33.03.01.

Secretaría de Gestión de Riesgos. 2017. Informes de situación - época lluviosa 2017. http://www.gestionderiesgos.gob.ec/informes-de-situacion-epocalluviosa-2017/

Senplades (Secretaría Nacional de Planificación y Desarrollo). 2016. Resultados de la evaluación del sismo del 16 de abril. Secretaría Nacional de Planificación y Desarrollo. Recuperado de https://issuu.com/ publisenplades/docs/resultados_de_la_evaluaciondelsismo.

Sobrino, J. A., Z.L. Li, M.P. Stoll and F. Becker. 1996. Multi-channel and multi-angle algorithms for estimating sea and land surface temperature with ATSR data. Intern. J. Rem. Sens., 17(11): 2089-2114. DOI:10.1080/01431169608948760.

Thielen, D., J. Cevallos, T. Erazo, I. Zurita, J. Figueroa, J. Quintero, N. Matute, G. Velásquez y M. Puche. 2015. Dinámica de eventos climáticos extremos en la cuenca del río Portoviejo, Manabí. Rev. La Técnica 14: 80-91.

Tiscama, A. 2017. Dos sistemas atmosféricos han influenciado las condiciones atmosféricas del país. Bol. Prensa Inst. Nal Meteor. Hidrol. 13 de enero de 2017.

Valencia, M., A. Figueroa, D. Ruiz, J. Otero, J. Martínez, V. Ceballos y D. González. 2014. Metodológica para el análisis de vulnerabilidad en cuencas abastecedoras de agua ante la variabilidad climática. Ingenierías, 13 (25): 29-43. Recuperado de http://revistas.udem.edu.co/index.php/ingenierias/ article/view/994/986.

Vargas-Jiménez, I. 2012. La entrevista en la investigación cualitativa: nuevas tendencias y retos. the interview in the qualitative research: trends and challengers. Rev. Electr. Calidad Educ. Sup., 3 (1): 119-139.

Vega, R., V. Flores, G. Fleites y A. Montalvo. 2013. Agresividad de las precipitaciones en la subcuenca del río San Marcos, Puebla. México. Invest. Geogr., Bol. Inst. Geogr., UNAM. 83: 28-40. DOI: 10.14350/rig.33480. 